\title{
EL DERECHO DEL TRABAJO CHILENO DURANTE EL SIGLO $\mathrm{XX}$
}

\author{
LUIS LIZAMA PORTAL* \\ Universidad de Chile
}

\begin{abstract}
RESUMEN: En este artículo se describe y analiza, desde una perspectiva crítica, el devenir histórico del derecho del trabajo chileno durante el siglo pasado. Comienza el autor, haciéndose cargo de las primeras leyes sociales en Chile (con o sin contenido laboral), centrándose en el contexto político y social en que fueron dictadas. Continúa su desarrollo histórico con las ideologías que se han enfrentado en el terreno de la legislación laboral desde la segunda mitad del siglo XX, el rol del Estado, el mercado y las formas de producción modernas que han debido hallar reconocimiento en la ley. Culmina con un estudio sobre la dogmática laboralista nacional y el papel preponderante que en ella tienen los dictámenes de la Dirección del Trabajo.
\end{abstract}

Palabras clave: Historia del Derecho del trabajo, Código del Trabajo de 1931, Leyes sociales chilenas, Plan Laboral, Flexibilidad, Doctrina laboral, Dirección del Trabajo.

ABSTRACT: This article describes and analyzes, from a critical perspective, the historical development of the Chilean labor law during the last century. Begins the author, taking charge of the first social laws in Chile (with or without labor content), focusing on political and social context in which they were issued. Continues its historical development with the ideologies that have clashed in the field of labor law since the second half of the twentieth century, the role of State, market and modern production methods that have to find recognition in the law. Culminates with a study of the dogmatic labor law doctrine and its preponderant role in the opinions of the Department of Labor.

Key words: Social security, Chilean constitution, Pension Reform, individual capitalization, subsidiarity, solidarity.

\section{INTRODUCCIÓN}

Las bases del derecho del trabajo nacional surgen a comienzos del siglo XX, específicamente con el establecimiento de la ley sobre descanso dominical $\mathrm{N}^{\circ} 1.990$, de 29 de agosto de $1907^{1}$.

El derecho del trabajo ${ }^{2}$ emerge como una rama autónoma del derecho civil, descodificándose de este, cuando se dicta una regulación del trabajo retribuido prestado en régimen

\footnotetext{
* Abogado y Magíster en Derecho, Universidad de Chile. Profesor de Derecho del Trabajo en la misma universidad.

1 La mayoría de la doctrina nacional señala que la primera ley social fue la ley $\mathrm{N}^{\circ} 1.838$, de 20 de febrero de 1906 , sobre Habitaciones Obreras. Sin embargo, esta iniciativa legal no guarda relación con el derecho laboral puesto que no se refiere a la regulación del trabajo asalariado al margen del Código Civil, sino que su propósito era la edificación de viviendas higiénicas para destinarlas al arriendo o compra de los trabajadores que habían emigrado del campo a la ciudad y que vivían en condiciones paupérrimas en la urbe. Sobre el particular, véase, THAYER, William. "Orígenes, evolución y perspectivas del derecho laboral chileno”, en: Estudios Públicos No 54, pp. 223-240. Santiago, Chile: Centro de Estudios Públicos.

2 Por derecho del trabajo entendemos, siguiendo a Palomeque, la ordenación jurídica del trabajo asalariado o prestado por cuenta ajena. La disciplina se centra en las relaciones jurídicas (el contrato de trabajo y las relaciones colectivas de representación y defensa de intereses resultantes) que se establecen entre quienes realizan un trabajo retribuido y dependiente por cuenta de y para otra persona (trabajadores) y quienes los retribuyen y hacen suyo los resultados de la actividad laboral contratada (empleadores).
} 
de ajenidad, dependencia y libertad, de acuerdo con principios diferentes a los propios de la norma civil, esto es, cuando la intervención del Estado a favor de los trabajadores signifique limitar la autonomía de la voluntad ${ }^{3}$.

La idea de que el derecho del trabajo se descodificó del derecho civil, ha sido desarrollada por autores que ven en el origen del derecho laboral chileno el caso más sobresaliente de una descodificación formal y material ${ }^{4}$. Lo anterior, porque con el primer Código del Trabajo surgió un nuevo derecho, que descodificó el contrato de arrendamiento de servicios inmateriales que el Código Civil regulaba en los párrafos 7, 8 y 9 del Título XXVI del Libro IV 5.

Desde otra perspectiva, el derecho del trabajo es una categoría cultural, fruto del sistema capitalista industrial, que no constituye la respuesta normativa al conflicto de trabajo en general, sino que es la reacción ante el conflicto que se produce entre el capital y el trabajo asalariado en la sociedad capitalista industrial, entendido como el motor de todas sus contradicciones, o sea, de un conflicto central o paradigmático ${ }^{6}$.

Este conflicto social podrá ser resuelto por la intervención del Estado a través de una legislación protectora del trabajo asalariado, o bien, con la organización y movilización del proletariado industrial (movimiento obrero) que articula una reacción de autotutela colectiva de los propios trabajadores frente a su injusta situación ${ }^{7}$.

De este modo, nos parece sensato sostener que el derecho del trabajo se consolida como concepto autónomo con la concurrencia de los siguientes factores: el desarrollo acelerado de lo que se llamó legislación social, el reforzamiento del intervencionismo orgánico

\footnotetext{
Frente al dogma liberal de la "igualdad de los contratantes", el derecho laboral se apoya en la "idea de la asimetría del contrato de servicios a causa de la desigualdad de poder económico entre el empleador y el trabajador"; frente al dogma del "abstencionismo normativo del Estado", el derecho del trabajo supone naturalmente la "intervención de este para la protección del contratante débil en la relación individual de trabajo"; por último, frente al dogma liberal del "entendimiento directo entre los individuos en el mercado de trabajo", el nuevo derecho acepta "la dimensión colectiva de las relaciones laborales, admitiendo con más o menos amplitud la participación de las asociaciones y coaliciones profesionales en la fijación de las condiciones de trabajo". Sobre el particular, véase, PALOMEQUe, Manuel-Carlos. Derecho del Trabajo e Ideología. Medio siglo de formación ideológica del Derecho español del trabajo (1873-1923). Madrid, España: Editorial Tecnos, 1980, p. 13.

4 Se entiende por "descodificación formal" aquella que establece un derecho especial o nuevo, por "descodificación material" aquella que establece derecho singular a través de leyes modificatorias de un código, y por "descodificación formal y material" aquella que establece derecho singular mediante leyes extravagantes. Sobre el particular, véase, GUZMÁN BRITO, Alejandro. "Codificación, descodificación y recodificación del derecho civil chileno", en: Revista de Derecho y Jurisprudencia y de Gaceta de los Tribunales, Tomo 90, № 2, pp. 39-62. Santiago, Chile: Editorial Jurídica de Chile.

5 Sobre la descodificación, véase, IRTI, Natalino. La edad de la descodificación. Madrid, España: Editorial José Bosch, 1992.

6 Palomeque, Manuel-Carlos y Álvarez de la Rosa, Manuel. Derecho del Trabajo. -6a edición-. Madrid, España: Editorial Centro de Estudios Ramón Areces, S.A., 1998. En consideración a lo sostenido, no comparto la opinión de algunos autores nacionales que han señalado que el derecho laboral chileno encuentra sus raíces histórico-sociales y ético-jurídicas en el derecho indiano. Al respecto, véase, THAYER, William. "Notas sobre génesis y desarrollo del derecho del trabajo en la República de Chile". En: VV.AA. Derecho del Trabajo: Normas y realidad. Estudios en homenaje al profesor Ramón Luco Larenas. Santiago, Chile: Universidad Nacional Andrés Bello, 1992, pp. 75-100.

7 En Chile, las primeras organizaciones obreras se fundan a fines del siglo XIX y comienzos del siglo XX. Estas organizaciones se crean para defender los intereses sociales y económicos de sus miembros, y para luchar contra las difíciles condiciones de vida y de trabajo de los asalariados, en particular, en la actividad minera, en donde se produjeron los primeros conflictos laborales de envergadura. Desde un comienzo, el movimiento obrero recibe la influencia de las ideas anarquistas y socialistas. Sobre el particular, véase, DESHAZO, Peter. Urban workers and labor unions in Chile, 1902-1927. University of Wisconsin Press, 1983. Grez Toso, Sergio. De la "regeneración del pueblo" a la huelga general. Génesis y evolución histórica del movimiento popular en Chile (1810-1890). Santiago, Chile: Colección Dibam, Ediciones Ril, 1997.
} 
del Estado, la regulación singular del contrato de trabajo al margen de los arrendamientos de servicios, la dictación del primer Código o recopilación oficial de leyes del trabajo, la constitución de la Organización Internacional del Trabajo y, finalmente, la elaboración doctrinal de la nueva disciplina ${ }^{8}$.

En nuestra opinión, la conformación progresiva del derecho del trabajo chileno como un derecho singular con normas y principios propios, diferentes del derecho civil, se produce durante el siglo XX y puede dividirse en las siguientes etapas:

La legislación social previa a 1924 (1907-1924);

La conformación de la legislación laboral chilena (1924-1931);

El Código del Trabajo de 1931(1931-1978);

La flexibilización de la legislación laboral y las reformas en democracia (1978-2000).

\section{LA LEGISLACIÓN SOCIAL PREVIA A $1924^{9}$}

Con la expresión legislación social ${ }^{10}$ se ha pretendido comprender el conjunto de leyes y normas administrativas que regulaban de alguna manera la cuestión social ${ }^{11}$.

Antes de analizar la legislación social de este período, es necesario tener presente que las leyes relativas a las relaciones del capital y el trabajo se encontraban dispersas en los diferentes cuerpos legales vigentes a la época: el Código Civil, el Código de Comercio, el Código de Procedimiento Civil y el Código de Minería. Indudablemente, los principios que inspiraban estas relaciones eran los propios del derecho civil: libertad contractual e igualdad jurídica de los contratantes.

El Código Civil (1855) regulaba el contrato de arrendamiento de criados domésticos, en que una de las partes prometía prestar a la otra, mediante un salario, cierto servicio, determinado por el contrato o por la costumbre del país; los contratos para la confección de una obra material que se aplicaban tanto a los contratistas, empresarios, artesanos y obreros, y el

\footnotetext{
Palomeque, Manuel-Carlos. Derecho del Trabajo e Ideología. Madrid, España: Editorial Tecnos, 2011.

9 En este apartado se utilizó un trabajo inédito de la historiadora Cristina Castro. Al respecto, véase CASTRO, Cristina. Antecedentes jurídicos de las leyes sociales de 1924. Memoria de prueba (Programa de Magíster en Historia de América). Santiago, Chile: Universidad de Chile, 2000.

10 En el derecho comparado se utiliza la expresión "legislación obrera" para referirse a la misma idea. Sobre el particular, véase Palomeque, Manuel-Carlos, Derecho del Trabajo... (n. 8). En Chile, los autores han usado también los términos "derecho obrero", "derecho o legislación del trabajo", "legislación industrial” y "derecho o legislación social”. ESCRÍBAR MANDIOLA, Héctor. Tratado de Derecho del Trabajo. Santiago, Chile: Editorial Zig-Zag, 1944, pp. 15-19.

11 Por "cuestión social" se ha comprendido todas las consecuencias sociales, laborales e ideológicas de la industrialización y urbanización nacientes a la época, esto es, una nueva fuerza de trabajo dependiente del sistema de salarios, la aparición de problemas cada vez más complejos, pertinentes a vivienda obrera, atención médica y salubridad, la construcción de organizaciones destinadas a defender los intereses de la nueva "clase trabajadora", huelgas y demostraciones callejeras, choques armados entre los trabajadores y la policía o los militares, y cierta popularidad de las ideas extremistas, con una consiguiente influencia sobre los dirigentes de los trabajadores. Al respecto, véase Morris, James O. Las elites, los intelectuales y el consenso. Estudio de la Cuestión Social y del sistema de relaciones industriales de Chile. Santiago, Chile: Editorial del Pacífico, 1967, p. 79.
} 
contrato de arrendamiento de servicios inmateriales, que regulaba el trabajo de los empleados domésticos, de los obreros y de los empleados particulares ${ }^{12}$.

Por su parte, el Código de Comercio (1865) al regular los contratos de los hombres de mar, contenía cuidadosas disposiciones de protección obrera, como la exigencia de escrituración del contrato entre el naviero y los marineros.

A su vez, el No 2 del artículo 467 del Código de Procedimiento Civil (1906), declaraba inembargables "[l] os jornales y salarios de los jornaleros y criados", y en el No 12 del mismo artículo, "[l]os objetos indispensables al ejercicio personal del arte u oficio de los artistas artesanos y obreros de fábrica; y los apeos animales de labor y material de cultivo necesarios al labrador o trabajador del campo para la explotación agrícola, hasta la suma de cuatrocientos pesos y a la elección del mismo deudor", constituyendo estas las primeras normas protectoras de las remuneraciones de los asalariados.

Finalmente, el Código de Minería (1888) trataba el arrendamiento por tiempo de servicios de operarios, que reglamentaba minuciosamente las relaciones de patrones y operarios, exigiendo la escrituración de este contrato si excedía de un año y declarando que el operario no estaba obligado a permanecer en dicho servicio por más de cinco años contados desde la fecha de la escritura.

A este confuso y obsoleto panorama de legislación obrera, que no contemplaba los cambios en el sistema de producción y del proceso de industrialización, se le sumaban algunas leyes sociales específicas dispersas:

a) La ley $\mathrm{N}^{\circ} 1.838$, de 20 de febrero de 1906, sobre habitaciones obreras ${ }^{13}$.

b) La ley $\mathrm{N}^{\circ} 1.990$, de 29 de agosto de 1907, sobre descanso dominical, la que fue modificada debido a su excesiva rigidez, por la ley $\mathrm{N}^{\circ} 3.321$ de 5 de noviembre de $1917^{14}$.

c) La ley $\mathrm{N}^{\circ} 2.675$, de 4 de septiembre de 1912, sobre protección de la infancia desvalida.

d) La ley $\mathrm{N}^{\circ} 2.789$, de 31 de julio de 1913, sobre inembargabilidad de cuotas mortuorias $^{15}$.

\footnotetext{
12 De acuerdo con la opinión de Thayer, todas estas disposiciones se encuentran derogadas tácitamente por el Código del Trabajo. Sobre el particular, véase, THAYER, William. "Notas sobre... (n. 6).

13 Esta es la primera ley específicamente social que se dicta, dirigida a solucionar una de las necesidades más urgentes de la población obrera, aunque no constituye en sí una ley laboral. Durante la discusión en el Congreso queda la idea que todos los partidos políticos están de acuerdo con la necesidad de facilitar el acceso a la habitación barata e higiénica a los trabajadores, atendidas las condiciones de hacinamiento existentes en conventillos y la proliferación de enfermedades infecciosas, especialmente la viruela.

14 A pesar de lo lógico que parece la regulación del descanso semanal, a principios del siglo XX, esta no era una idea aceptada por todos los sectores. En el Congreso se discutió por qué el descanso semanal debía ser otorgado en domingo y no en otro día de la semana. Es especialmente interesante la disputa entre radicales y conservadores sobre la implicancia religiosa del día domingo. El reglamento de esta ley es el decreto $\mathrm{N}^{\circ} 101$ de 16 de enero de 1918 , que actualmente se encuentra vigente por expresa disposición del artículo $3^{\circ}$ transitorio del Código del Trabajo de 1994.

15 Esta ley declaraba inembargables los socorros en dinero hasta por un monto de $\$ 10.000$. Estas cuotas mortuorias eran otorgadas por corporaciones civiles con personalidad jurídica a sus asociados o a las familias de estos.
} 
e) La ley $\mathrm{N}^{\circ} 2.951$, de 25 de noviembre de 1915, sobre sillas en los establecimientos de comercio $^{16}$

f) La ley $\mathrm{N}^{\circ} 3.170$, de 27 de diciembre de 1916, sobre accidentes del trabajo, ${ }^{17}$.

g) La ley $\mathrm{N}^{\circ} 3.186$, de 13 de enero de 1917, sobre sala cuna en los establecimientos industriales con cincuenta o más mujeres ${ }^{18}$.

h) La ley $\mathrm{N}^{\circ} 3.379$, de 10 de mayo de 1918, que creó la Caja de Retiro y Previsión Social de los Ferrocarriles del Estado ${ }^{19}$.

i) La ley $\mathrm{N}^{\circ}$ 3.607, de 27 de febrero de 1920, que crea la Caja de Crédito Popular.

j) La ley $\mathrm{N}^{\circ} 3.915$, de $1^{\circ}$ de marzo de 1923, sobre peso de sacos de carguío.

La regulación social administrativa anterior a 1924 era la siguiente:

a) El decreto $\mathrm{N}^{\circ} 730$, de 5 de abril de 1907, del Ministerio de Industrias y Obras Públicas, que crea la Oficina Estadística del Trabajo ${ }^{20}$.

b) El decreto $\mathrm{N}^{\circ} 1938$, de 4 de noviembre de 1919, del Ministerio de Industria, que reglamenta la Oficina del Trabajo.

c) El decreto $\mathrm{N}^{\circ}$ 1527, de 18 de agosto de 1914 del Ministerio de Industrias y Obras Públicas, que creó un "Servicio oficial gratuito de colocación de obreros".

Durante la discusión parlamentaria de las primeras leyes sociales, existieron dos posiciones que propugnaban una solución defensiva del Estado liberal para dictar leyes protectoras de los trabajadores, integrando e institucionalizando el conflicto entre el capital y el trabajo asalariado, en términos compatibles con la estabilidad del sistema económico capitalista. Por una parte, los conservadores, animados por la idea de la caridad cristiana y, por la otra, liberales y radicales, entusiasmados con la justicia social.

En cambio, los partidos de izquierda sostuvieron una actitud crítica hacia la legislación social. Los anarquistas se manifestaron en contra de la regulación y los socialistas obreros, que después se transformarían en comunistas, plantearon que estos intentos legislativos de la burguesía reformista solo consolidaban y legitimaban el sistema de explotación econó-

\footnotetext{
16 Esta ley es la primera que impone una obligación concreta a los capitalistas o empleadores y nace por el impulso del Partido Liberal. Esta norma permitía asegurar condiciones básicas de trabajo en los establecimientos de comercio ya que sancionaba con multas la infracción de estas obligaciones. Esta disposición se encuentra actualmente en el artículo 193 del Código del Trabajo de 1994.

17 Esta ley es una de las más importantes, ya que establece una indemnización de cargo del empresario en caso de accidentes del trabajador. Sin embargo, adolecía de un defecto esencial al exceptuar de la responsabilidad patronal los accidentes debidos a culpa grave de la víctima.

18 Esta es una ley muy importante que también tiene vigencia hasta el día de hoy, aunque se ha reducido el número de mujeres necesarias para la implementación de la sala cuna a 20 trabajadoras de cualquier edad y estado civil.

19 Esta es la primera ley de previsión social dictada en Chile y favoreció a más de 25.000 obreros y empleados. Estableció pensiones de retiro y creó diversos servicios de índole social, tales como seguro de vida, asistencia médica, asignación familiar y asistencia hospitalaria.

20 Según la doctrina nacional, esta Oficina de Estadísticas es el antecedente de la Dirección del Trabajo creada por ley No 4.053, de 1924.
} 
mica de los capitalistas frente a los obreros: "con las leyes de sindicatos se les controla y con la participación en utilidades se les presiona" 21.

Todas estas leyes estaban destinadas a mejorar de una u otra manera la situación de las clases populares. Sin embargo, estas no obedecían a un programa social destinado a solucionar el conflicto social existente, que, además, era negado por los parlamentarios y calificado como una obra de agitadores de profesión.

La legislación no consideraba la regulación del conflicto colectivo, ni menos del ejercicio del derecho a huelga, la solución de las disputas laborales entre trabajadores y empleadores, los sindicatos, sus sistemas de remuneraciones y la participación en las utilidades ${ }^{22}$.

Con el objeto de ilustrar las concepciones ideológicas de la época, quizás valga la pena dar cuenta del interesante debate que se produjo en la Cámara de Diputados a propósito de la ley sobre descanso dominical.

El diputado radical Suárez Mujica sostuvo, durante la discusión parlamentaria, sorprendentes argumentos relativos a la libertad de trabajo, para oponerse a la aprobación de la ley de descanso dominical, en los siguientes términos:

"Creo que este proyecto no responde a una necesidad realmente sentida en nuestro país. El ejercicio de la libertad individual es absoluta en esta materia, i cada cual puede hacer lo que le plazca (...).

En Chile todos sabemos que los obreros trabajan como i cuando quieren, sin que los capitalistas se impongan jamás a los obreros; por el contrario son estos quienes dictan e imponen la lei a sus patrones (...).

Además, a mi juicio, esta lei atenta contra la libertad del trabajo, puesto que impide entregarse a él a los que quieran hacerlo en ciertos y determinados días" 23 .

Malaquías Concha, importante líder del Partido Demócrata, defiende la aprobación de la ley, utilizando el argumento de la legislación extranjera:

"No hai hoy día, un solo país civilizado que no haya establecido el descanso dominical, no como una cuestión relijiosa, no como una cuestión de santificar el día domingo, sino como una cuestión meramente fisiolójica: la necesidad de dar al organismo humano un indispensable descanso para reparar las fuerzas físicas".

\footnotetext{
21 Ramírez Necochea, Hernán. Origen y formación del Partido Comunista de Chile. Santiago, Chile: Editorial Austral, 1965, p. 113.

22 En los casos de conflicto entre trabajadores y empresarios, se utilizó un Decreto dictado por el Ejecutivo, de 14 de diciembre de 1917, que prescribía que "en los casos de dificultades en el orden colectivo que se produjeran entre patrones y obreros o empleados sobre condiciones de trabajo, el intendente o gobernador respectivo, a solicitud de cualquiera de los interesados, debería proceder a invitar a ambas partes para que, dentro del término de 24 horas, procedieran a designar tres representantes, a fin de constituir una Junta de Conciliación y Arbitraje". Esta fue la primera medida gubernativa de orden práctico para solucionar los conflictos colectivos, aunque su aceptación era meramente facultativa, tanto para trabajadores como para los empleadores.

23 Congreso Nacional. Cámara de Diputados. Boletín de Sesiones Ordinarias de la Cámara de Diputados, 14 de junio de 1907, p. 187.
} 
En la misma intervención se refiere a la apreciación del diputado Suárez Mujica respecto de los obreros y manifiesta, textualmente:

"No se les juzgue a todos por igual; no son todos los obreros esos que van a las tabernas de las calles de San Pablo i San Diego i que andan luciendo la mona por las calles. No señor. Por cada ciento que hacen esto, hai mil, dos mil i mas obreros que llenan sus tareas, que son hombres pacíficos i sobrios, que dedican el domingo a estar con sus familias i educar a sus hijos, i no se emborrachan en las tabernas"24.

\section{LA CONFORMACIÓN DE LA LEGISLACIÓN LABORAL CHILENA (1924-1931)}

En los comienzos de la década del veinte, el sistema parlamentario establecido de facto en el país funcionaba deficientemente, cuestión que se expresa en rotativas ministeriales interminables y una casi nula labor del Congreso.

Arturo Alessandri, que había sido elegido Presidente de la República con un programa que pretendía establecer una legislación que resolviera los problemas sociales, encarga a Moisés Poblete Troncoso la redacción de un Código del Trabajo, que es enviado al Congreso para su discusión en 1921.

Durante el lento debate parlamentario, conservadores y liberales discutían, entre otros temas, respecto de un sistema de arbitraje y conciliación para la resolución de los conflictos colectivos, que para unos debía ser obligatorio y para otros facultativo y voluntario.

Ambos sectores querían solucionar el conflicto sin perder el control de la situación. Así, por ejemplo, respecto del nombramiento de los miembros de los tribunales del trabajo, se proponía que tres fueran nombrados por el empleador y dos por los trabajadores. De igual modo, se aspiraba a controlar a los sindicatos a través del sistema de voto acumulativo.

El debate parlamentario no avanzó en la aprobación de la legislación propuesta por el Ejecutivo. El Congreso se negó a discutir más leyes mientras no se discutiera el proyecto de dieta parlamentaria. En ese momento, la situación era crítica. Los ministros no duraban en sus cargos y un grupo de oficiales jóvenes se tomó el poder. Es el llamado "ruido de sables".

Los oficiales rebeldes se reunieron con el presidente Alessandri, para exigirle la dictación inmediata de ciertas leyes. El Presidente negoció con el Congreso y este aprobó rápidamente la legislación que durante años había vegetado en sus Cámaras. Alessandri estaba convencido que los militares se retirarían, circunstancia que no se produjo. Los militares le exigieron que disolviera el Congreso Nacional. Alessandri se niega y renuncia a su cargo, quedando una Junta Militar al mando de la Nación.

Las leyes sociales que son dictadas en 1924, por la presión de la oficialidad joven, son las siguientes:

a) La ley $\mathrm{N}^{\circ} 4.053$, de 29 de septiembre de 1924, sobre contrato de trabajo obrero ${ }^{25}$.

\footnotetext{
$24 \quad$ Ibid. p. 139.

25 Esta ley reglamenta el contrato de trabajo de los obreros, limita su duración y la jornada de trabajo, legisla sobre el trabajo femenino e infantil, régimen de la fábrica, salarios, contratos colectivos, higiene y seguridad, y crea la Dirección General del Trabajo
} 
b) La ley $\mathrm{N}^{\circ} 4.054$, de 26 de septiembre de 1924, sobre seguro social obligatorio de enfermedad, invalidez y vejez ${ }^{26}$.

c) La ley $\mathrm{N}^{\circ} 4.055$, de 26 de septiembre de 1924, sobre indemnización de accidentes del trabajo y enfermedades profesionales ${ }^{27}$.

d) La ley $\mathrm{N}^{\circ} 4.056$, de 1 de diciembre de 1924, sobre juntas de conciliación y tribunales de arbitraje ${ }^{28}$.

e) La ley $\mathrm{N}^{\circ} 4.057$, de 29 de septiembre de 1924, sobre organización sindical ${ }^{29}$.

f) La ley $\mathrm{N}^{\circ} 4.058$, de 30 de septiembre de 1924, de sociedades cooperativas.

g) La ley $\mathrm{N}^{\circ} 4.059$, de 27 de septiembre de 1924, sobre contrato de trabajo de empleados particulares ${ }^{30}$.

También se dictó el decreto ley $\mathrm{N}^{\circ} 44$, de 14 de octubre de 1924, que crea el Ministerio de Higiene, Asistencia, Previsión Social y Trabajo, modificado posteriormente por el decreto ley $\mathrm{N}^{\circ} 323$ de 25 de febrero de 1925.

Esta legislación laboral fue un resultado híbrido entre el proyecto del Ejecutivo y una propuesta de los senadores conservadores. La mayoría de los autores chilenos consideran que aunque imperfecta y llena de vacíos, esta regulación constituyó un avance significativo para la época ${ }^{31}$.

Se destaca fundamentalmente el hecho que la legislación reconociera la existencia de las partes sociales y la intervención del Estado en las relaciones de trabajo, resaltándose dos rasgos fundamentales: el reconocimiento de la libertad de contratación y el despido de la fuerza de trabajo, y un sindicalismo radicado en la empresa, cuya principal actividad era la negociación colectiva ${ }^{32}$.

Los legisladores, guiados por sus intereses políticos, fueron incapaces de solucionar seriamente y a tiempo los problemas sujetos a su consideración. Los mismos representantes de los sectores populares en el Congreso, no tenían clara su postura frente a la legislación

\footnotetext{
26 Esta ley, la única que no provenía del proyecto de Moisés Poblete, fue obra del médico conservador Exequiel González Cortés. El proyecto de ley fue presentado a la Cámara de Diputados el 27 de noviembre de 1922 y no fue estudiado por la Comisión Mixta Parlamentaria, en espera de la discusión sobre los seguros sociales que regulaba el proyecto del Ejecutivo, los que cubrían, además, el riesgo de paro forzoso.

27 Esta ley consagra la teoría del riesgo profesional, al suprimir la excepción de culpa grave de la víctima que exigía la ley No 3.170. Además, establece un seguro voluntario por dicho riesgo e instituye un procedimiento judicial especial.

28 Esta ley establece los tribunales de conciliación y arbitraje para los conflictos colectivos de trabajo. La conciliación era obligatoria y el arbitraje facultativo. También reconoce el derecho a huelga, sujetándolo a requisitos en su ejercicio.

29 La ley crea y regula el funcionamiento de los sindicatos industriales y profesionales, y concede, a favor de los primeros, participación en las utilidades en la empresa.

30 Esta es la única materia que el proyecto de Alessandri no contemplaba específicamente. Atañe a los asalariados del comercio, de las oficinas y de la industria, en cuyo trabajo predomina el esfuerzo intelectual. La ley les otorga diversos beneficios, como limitación de horas de trabajo, vacaciones pagadas, licencia por enfermedad, gratificación, indemnización por años de servicio, fondos de retiro y seguro de vida.

31 Walker Errázuriz, Francisco. Derecho del Trabajo y Relaciones del Trabajo. Santiago, Chile: Editorial Jurídica Ediar ConoSur Ltda., 1984, p. 96

32 Tapia Guerrero, Francisco, "La flexibilidad en el derecho del trabajo chileno". En: VV.AA. Experiencias de flexibilidad normativa. Las transformaciones del derecho del trabajo. Santiago, Chile: Universidad Nacional Andrés Bello, p. 60.
} 
social; participaban en las elecciones parlamentarias, pero al mismo tiempo no estaban dispuestos a apoyar una legislación obrera "reformista burguesa".

El estancamiento llegó a ser tal, que los militares presionaron a los parlamentarios para la aprobación de todas las leyes sociales discutidas ${ }^{33}$.

El presidente Alessandri, exiliado en Francia, le escribe una sentida carta a su amigo y ex ministro Moisés Poblete Troncoso, que revela el trasfondo de la discusión parlamentaria sobre la legislación social en la época:

“Todavía, mi amigo, muchas veces en las calles de París no faltan compatriotas que, tatareando el último tango del cabaret de la noche, me detienen para saludarme cariñosamente, para decirme muchas cosas simpáticas y agradables, pero, frecuentemente, al despedirse, como una obsesión o un estribillo ya muy conocido para mí, terminan diciendo: 'Lo que no le perdonamos es que Ud. le dio muchas alas al roto y lo levantó’. ¡Pobres gentes! Los miro, sonrío y sigo mi camino (...).

Perseveran empecinados creyendo que fui yo quien creó el problema social en Chile cuya existencia niegan. Sería lo mismo que atribuirme la generación de la lluvia, del viento, del bueno o mal tiempo" 34 .

Con posterioridad a septiembre de 1924 , se aprobaron, entre otras, las siguientes disposiciones legales ${ }^{35}$ :

a) El decreto ley No 24, de 4 de octubre de 1924 y el decreto ley No 272, de 24 de febrero de 1925, sobre trabajo nocturno en las panaderías.

b) El decreto ley No 44, de 14 de octubre de 1924, que creó la Secretaría de Estado de Higiene, Asistencia, Previsión Social y Trabajo.

c) El decreto ley No 442, de 28 de marzo de 1925, sobre protección de la maternidad obrera.

d) El decreto ley No 857, de 11 de septiembre de 1925, sobre empleados particulares, sustitutivo de la ley No 4.059, de 1924.

e) El decreto ley No 2.100, de 31 de diciembre de 1927, sobre tribunales del trabajo.

La primera Constitución que contempló disposiciones de carácter laboral fue la de 1925, que en su artículo 10, numerales 5, 10 y 14, se refería a la protección del derecho de

33 Según Morris, el movimiento de los oficiales jóvenes del Ejército habría actuado motivado por intereses propios y no solamente por una preocupación frente a la inactividad parlamentaria.

34 Poblete Troncoso, Moisés. El Derecho del Trabajo y la Seguridad Social en Chile. Santiago, Chile: Editorial Jurídica de Chile, 1949, p. 27.

35 Además, el 10 de agosto de 1925 se dictaron ocho decretos leyes mediante los cuales se ratificaron los siguientes Convenios de la Organización Internacional del Trabajo: el Convenio No 1 sobre horas de trabajo (industria), 1919; el Convenio No 3 sobre la protección de la maternidad, 1919; el Convenio No 5 sobre la edad mínima (industria), 1919; el Convenio No 6 sobre el trabajo nocturno de los menores (industria), 1919; el Convenio No 11 sobre el derecho de asociación (agricultura), 1921; el Convenio No 12 sobre la indemnización por accidentes del trabajo (agricultura), 1921; el Convenio No 13 sobre la cerusa (pintura), 1921; y el Convenio No 14 sobre el descanso semanal (industria), 1921. 
asociación, la función social de la propiedad y la protección a todo trabajo o industria que no se opusiera a las buenas costumbres, a la seguridad o a la salubridad públicas ${ }^{36}$.

Este período culminó con la dictación del Código del Trabajo durante el gobierno de Carlos Ibáñez. El Código no fue promulgado como tal, sino como un texto refundido y ordenado de las leyes sociales establecidas entre los años 1915 y 1931. No obstante, las comisiones técnicas que el Gobierno nombró para que redactaran el proyecto de Código no solo incluyeron en él las leyes vigentes a la época, sino que también una nueva regulación que modificaba y complementaba la existente, respecto de trabajadores agrícolas, empleados domésticos, trabajadores a domicilio y trabajadores marítimos, entre otras materias.

Es por esta razón, que el Código del Trabajo fue dictado en el ejercicio de facultades extraordinarias de dudosa constitucionalidad, a través del decreto con fuerza de ley No 178 de 13 de mayo de $1931^{37}$.

\section{EL CÓdIGO DEL TRABAJO DE 1931 (1931-1978)}

El Código del Trabajo de 1931 constaba de 576 artículos distribuidos en 4 Libros: Libro I, Contrato de Trabajo; Libro II, De la protección de los Obreros y de los Empleados en el Trabajo; Libro III, Organizaciones Sindicales, y Libro IV, De los Tribunales y de la Inspección General del Trabajo.

Según nuestra doctrina, el Código del Trabajo inspiró sus disposiciones en los Convenios de la Organización Internacional del Trabajo y, por ello, la mayoría de las reformas que soportó durante sus aproximadamente cuarenta años de vigencia tuvieron como propósito adaptar la legislación interna a tales Convenios ${ }^{38}$.

Ahora bien, existe acuerdo en la comunidad dogmática laboral que las principales características del Código del Trabajo de 1931, eran las siguientes ${ }^{39}$ :

a) La distinción entre dos categorías de trabajadores: una común, constituida por los obreros, y una especial, más privilegiada, que son los empleados particulares.

b) Se excluye de la regulación a los funcionarios públicos y a los empleados de las empresas estatales con administración autónoma.

c) El régimen sindical distingue entre sindicatos industriales y sindicatos profesionales. Los sindicatos industriales estaban formados por todos los obreros de la empresa y te-

36 ThaYer, William. "Notas sobre... (n. 6), p. 83.

37 El Código del Trabajo fue dictado por Ibáñez sin la aprobación del Congreso Nacional. Las facultades que le había otorgado el Congreso no le autorizaban para dictar un Código que difería de las leyes preexistentes. Según Francisco Walker Errázuriz, este vicio de constitucionalidad del Código del Trabajo fue saneado con el transcurso del tiempo por la aplicación ininterrumpida de sus disposiciones y por las innumerables leyes que lo complementaron y modificaron, y también por el hecho que los tribunales aceptaron su aplicación desde el comienzo. Al respecto, véase, WALKER ERRÁZURIZ, Francisco, op. cit. (n. 31 ), p. 97.

38 THAYER, William. "Notas sobre... (n. 6), p. 84. Al contrario de lo sostenido por Thayer, el profesor Francisco Walker Linares sostenía en 1947: "De acuerdo con las ratificaciones anteriores, la legislación chilena debe armonizarse con las convenciones ratificadas, dando cumplimiento a sus preceptos; sin embargo, entre sus textos y los del Código del Trabajo y otras leyes, hay algunas contradicciones que no han sido corregidas". Al respecto, véase, WALKER LINARES, Francisco. Nociones Elementales del Derecho del Trabajo -4a edición-. Santiago, Chile: Editorial Nascimento, 1947, p. 163.

39 THAYER, William. "Notas sobre... (n. 6), p. 84. 
nía carácter único en ella. En cambio, los sindicatos profesionales eran de afiliación voluntaria, podían constituirse dentro de una empresa o por actividades afines y podían integrarse a ellos los patrones, los empleados, los obreros y los independientes ${ }^{40}$. Del mismo modo, las federaciones y confederaciones estaban prohibidas o restringidas.

d) El Estado interviene activamente en la relación laboral. No solo en la regulación y la fiscalización del cumplimiento de la legislación laboral, sino también en la resolución de los conflictos colectivos a través de las juntas de conciliación obligatorias ${ }^{41}$ y en la concesión de la personalidad jurídica de los sindicatos y su disolución ${ }^{42}$.

Las grandes reformas al Código del Trabajo de 1931 tuvieron por objeto igualar el trato ofrecido a los trabajadores que tenían, en la ley o en los hechos, mayores privilegios, con aquellos dependientes que se encontraban en una posición más desaventajada. Así por ejemplo, se extendieron a los obreros aquellos beneficios que el Código confería a los empleados particulares ${ }^{43}$. De igual modo, los beneficios legales o convencionales que obtenían los sindicatos más poderosos, fueron hechos extensivos a los trabajadores no sindicalizados o de sindicación débil ${ }^{44}$.

Durante la convulsionada época que comienza en 1964 y se extiende hasta 1973, se produjeron las más importantes reformas laborales durante la vigencia del Código del Trabajo de 1931, a saber ${ }^{45}$ :

a) La ley No 16.455, de 6 de abril de 1966, sobre terminación del contrato de trabajo, que estableció el principio de la estabilidad relativa en el empleo. Obligaba al empleador a despedir a los trabajadores invocando una causal específica; permitía al juez ordenar la reincorporación del trabajador si el despido era improcedente o injustificado, o bien, condenar al empleador al pago de una indemnización mínima de un mes de remuneraciones por año de servicio, y regulaba el despido colectivo ${ }^{46}$.

\footnotetext{
40 Esta era la materia más controvertida del Código del Trabajo de 1931 porque la regulación aplicable a los sindicatos industriales transgredía totalmente el principio de la libertad sindical. Asimismo, se planteaba que la excesiva intervención del Estado y sus funcionarios en los sindicatos también vulneraba tal principio. Sobre el particular, véase WALKER LINARES, Francisco, op. cit. (n. 38), pp. 370-375. Gamonal, Sergio. Derecho colectivo del trabajo (inédito), p. 20.

41 Las juntas de conciliación obligatoria eran organismos de integración tripartita, esto es, las conformaban representantes de los trabajadores, de los empleadores y del Estado.

42 Asimismo, los fondos de los sindicatos solo pueden ser depositados en cuentas administradas por el Banco del Estado.

43 Walker ERrázuriz, Francisco, op. cit. (n. 31), p. 100. Se puede citar como ejemplos de esta tendencia, las siguientes leyes: la ley No 6.939, de 26 de mayo de 1941, sobre gratificación obligatoria y participación a empleados y obreros de ciertas empresas de utilidad pública; la ley No 8.961, de 31 de julio de 1948, que dispone el pago de la semana corrida a los obreros; la ley No 9.581, de 3 de marzo de 1950, que modifica el régimen de gratificaciones e indemnizaciones por años de servicios de los empleados particulares; el decreto con fuerza de ley No 243, de 3 de agosto de 1953, que establece una indemnización por años de servicios para los obreros; el decreto con fuerza de ley No 244, de 1 de agosto de 1953, sobre salario mínimo para obreros agrí́colas; y el decreto con fuerza de ley No 245, de 31 de julio de 1953, sobre asignaciones familiares para obreros.

44 THAYER, William. "Notas sobre... (n. 6), p. 84.

45 Walker Errázuriz, Francisco, op. cit. (n. 31), pp. 99-101.

46 Ibid, p. 349
} 
b) La ley $\mathrm{N}^{\circ}$ 16.625, de 1 de febrero de 1967, sobre sindicalización campesina, que derogó la ley No 8.861. Esta fue la primera regulación que efectivamente respetó el principio de la libertad sindical en nuestro país y permitió una amplia sindicación en el agro, al establecer como base de la organización sindical a la comuna.

c) El decreto con fuerza de ley No 2, de 1967, sobre organización y funciones de la Dirección del Trabajo, que estableció que las principales funciones del organismo son la fiscalización de la aplicación de la legislación laboral y previsional, y la fijación del sentido y alcance de las leyes del trabajo ${ }^{47}$.

d) La ley No 17.074, de 31 de diciembre de 1968, sobre comisiones tripartitas resolutivas, que facultó al Presidente de la República para crear estas comisiones integradas con representantes de los trabajadores, empleadores y del Gobierno, destinadas a fijar condiciones de trabajo mínimas por rama de actividad ${ }^{48}$.

e) La ley No 17.398, de 9 de enero de 1971, que sustituyó el No 14 del artículo 10 de la Constitución de 1925, estableciendo el derecho a sindicarse en el orden de sus actividades o en su industria o faena, y el derecho de huelga. Además, que los sindicatos y las federaciones y confederaciones sindicales gozarán de personalidad jurídica por el solo hecho de registrar sus estatutos y actas constitutivas en la forma y condiciones que determinara la ley ${ }^{49}$.

f) La ley No 17.594 que otorgó personalidad jurídica a la Central Única de Trabajadores (CUT), la Agrupación Nacional de Empleados Fiscales (ANEF) y la Confederación de Empleados Particulares de Chile (CEPCH), entre otras organizaciones sindicales.

Es probable que el discurso del ex presidente Allende ante la Asamblea General de las Naciones Unidas, en diciembre de 1972, pueda reflejar de forma genuina la forma en que se concebían las relaciones laborales a dicha época:

"Vengo de Chile, un país pequeño pero donde hoy cualquier ciudadano es libre de expresarse como mejor prefiera, de irrestricta tolerancia cultural, religiosa e ideológica, donde la discriminación racial no tiene cabida. Un país con la clase obrera unida en una sola organización sindical, (...)

De este modo programado y coherente, la vieja estructura apoyada en la explotación de los trabajadores y en el dominio de unos pocos de los modos de producción, está siendo superada. En su reemplazo surge una nueva estructura, dirigida por los trabajadores que, puesta al servicio de la mayoría, está sentando las bases de un crecimiento que implica desarrollo auténtico (...)

Los trabajadores están desplazando a los sectores privilegiados del poder político y económico, tanto en los centros de labor como en las comunas y en el Estado" 50 .

\footnotetext{
47 Sobre la historia de la Dirección del Trabajo, véase LiZAma, Luis. La Dirección del Trabajo: una explicación de su facultad de interpretar la legislación laboral chilena. Santiago, Chile: Fundación Facultad de Derecho, Universidad de Chile, 1998, pp. 25-30.

48 Gamonal, Sergio, "Derecho colectivo... (n. 40), p. 32.

49 Ibid., p. 33.

50 Allende, Salvador. Obras escogidas (1970-1973). Barcelona, España: Editorial Crítica, 1989, pp. 333-357.
} 
Después del derrocamiento del presidente Allende, el gobierno militar que asume se muestra indeciso entre dos tendencias: una que quería introducir reformas radicales al régimen laboral y previsional vigente, y otra que postulaba modificar la legislación laboral, manteniendo los principios orientadores del Código del Trabajo de $1931^{51}$.

Durante la primera época del gobierno militar que comprende el período entre el 11 de septiembre de 1973 y el 15 de junio de 1978, las normas de carácter laboral que se dictaron tuvieron por objeto restringir la organización y la acción sindical.

Así, los decretos leyes No 12 y No 133, ambos de 1973, cancelaron la personalidad jurídica y disolvieron la Central Única de Trabajadores, y luego, el decreto ley No 198, de 1973, reguló y limitó de manera apreciable las actividades sindicales. Con posterioridad, el decreto ley No 2.346, de 1978, declaró ilícitas y disolvió diversas organizaciones sindicales, y el decreto ley No 2.347, de 1978, declaró ilícitas y contrarias al orden público las asociaciones o grupos de personas que asumieran la representación de sectores de trabajadores sin tener personería para ello.

La grave situación de persecución que afectó a los dirigentes sindicales y sus organizaciones durante los primeros años del gobierno militar, provocó que la Organización Internacional del Trabajo constituyera la Comisión de Investigación y de Conciliación en Materia de Libertad Sindical para que verificara in situ el deterioro de las condiciones necesarias para el ejercicio de los derechos por parte de los dirigentes sindicales chilenos y efectuara las recomendaciones pertinentes ${ }^{52}$. La Comisión concluyó, en su informe de 1974, que en el período investigado se había producido un "grave menoscabo a los principios de la libertad sindical para asegurar el respeto de las libertades civiles que son esenciales para el ejercicio de los derechos sindicales, sin los cuales el concepto mismo de estos derechos carece de sentido" 53 .

Por otra parte, también en lo relativo al derecho colectivo del trabajo, el decreto ley No 670, de 1974, terminó el funcionamiento de las comisiones tripartitas y, en 1977, el decreto ley No 1.765 restituyó algunas de las facultades resolutivas a dichas comisiones que, en definitiva, cesaron de funcionar en $1979^{54}$. Finalmente, los decretos leyes No 676 y No 930 modificaron la ley No 16.455 sobre terminación de la relación laboral.

\footnotetext{
$51 \mathrm{Al}$ respecto, véase, Hunneus, Carlos. El régimen de Pinochet. Santiago, Chile: Editorial Sudamericana, 2001.

52 La Comisión recomienda al Gobierno de Chile, en 1975, que los sindicalistas detenidos sean liberados o sometidos a un juicio conforme a procedimientos que ofrezcan todas las garantías en cuanto a la defensa y a un fallo imparcial; que se garantice el derecho de las personas a no ser detenidas sino en conformidad con el procedimiento penal ordinario; y que se garantice la seguridad de los detenidos contra todo tipo de apremios, mediante instrucciones específicas acompañadas de sanciones efectivas. Al respecto, véase, Oficina Internacional del Trabajo. La Situación Sindical en Chile. Informe de la Comisión de Investigación y de Conciliación en Materia de Libertad Sindical. Ginebra, Suiza, 1975, p. 127.

53 Ibid., p. 124. Es del caso, recordar que la Comisión de Investigación y de Conciliación en Materia de Libertad Sindical, creada en 1950 en virtud de un acuerdo adoptado entre la O.I.T. y el Consejo Económico Social de las Naciones Unidas, cuya función es investigar y examinar las quejas por violaciones a la libertad sindical, solo ha visto 5 casos en toda su historia: Japón (1964), Grecia (1965-66), Lesotho (1973-1975), Chile (1974-1975) y Estados Unidos (1981, referido a Puerto Rico). Sobre el particular, véase, ERmida, Óscar y VillaVicencio, Alfredo. “El Comité de Libertad Sindical”, en: Revista Derecho Laboral, Tomo XXXVI, No 169, pp. 82-83. Montevideo, Uruguay.

54 Gamonal, Sergio, "Derecho colectivo... (n. 40), p. 33.
} 


\section{LA FLEXIBILIZACIÓN DE LA LEGISLACIÓN LABORAL Y LAS REFORMAS EN DEMOCRACIA (1978-2000)}

\subsection{El Plan LabOral del GOBierno MiLitar ${ }^{55}$}

Una vez que las tendencias neoliberales se impusieron dentro del gobierno militar, se comenzó a reformar la legislación laboral en la perspectiva de una modernización con dicha inspiración.

Según Thayer, esta reforma de la legislación laboral tuvo por objeto hacer posible el funcionamiento de un sistema laboral individual y colectivo compatible con una economía social de mercado, donde no hubiera distingo entre empleados y obreros, y el Estado se enmarcara en su papel subsidiario y no compitiera con la empresa privada, que debía operar como gran motor del crecimiento económico ${ }^{56}$.

A la inversa, para Tapia en este proceso de reforma se impone una concepción de las relaciones de trabajo que centra el gobierno de las relaciones laborales en la empresa, se establecen limitaciones al derecho de negociación colectiva y de conflicto, y se perfila un esquema en el que el Estado solo fiscaliza y no interviene directamente en la relación laboral ${ }^{57}$.

Antes de entrar al detalle de esta nueva regulación laboral, parece pertinente analizar las disposiciones constitucionales que establecieron las bases para el modelo de relaciones de trabajo que se impuso a contar de 1981.

Los principios constitutivos del orden público laboral en la Constitución de 1980 son: el principio de la libertad de trabajo, el principio de la justa retribución, el principio de la no discriminación, el principio de la negociación colectiva, el principio de la libertad sindical y el principio de la autonomía colectiva o sindical $^{58}$.

De estos principios, merece especial consideración el tratamiento constitucional a la no discriminación laboral. El artículo 19 No 16 de la Constitución chilena prohíbe cualquier discriminación que no se funde en la capacidad o idoneidad personal, sin perjuicio de que la ley pueda exigir la nacionalidad chilena o límites de edad para determinados $\operatorname{casos}^{59}$.

La circunstancia que esta disposición constitucional no enumere un conjunto de criterios sujetos a sospecha de discriminación tales como la etnia, la religión o la opinión política, sino que se limite a señalar que los únicos criterios razonables para establecer diferencias de trato son la capacidad y la idoneidad personal, ha llevado a sostener que nuestra Constitución consagra a este respecto un "modelo antidiscriminatorio de sospecha abierta" 60 .

\footnotetext{
55 La expresión "Plan Laboral" fue utilizada para referirse a las modificaciones introducidas al derecho colectivo del trabajo a partir de 1979 por iniciativa del ministro José Piñera. Sin embargo, se suele designar bajo este nombre a toda la legislación laboral, individual y colectiva, dictada por el gobierno militar a contar del decreto ley No 2.200.

56 THAYER, William. "Orígenes, evolución y... (n. 1), p. 228.

57 TAPIA GUERrero, Francisco, op. cit. (n. 32), p. 65.

58 Gamonal, Sergio. Introducción al Derecho del Trabajo. Santiago, Chile: Editorial Jurídica ConoSur Ltda., 1998, p. 43.

59 Los artículos 19 y 20 del Código del Trabajo establecen que el ochenta y cinco por ciento, a lo menos, de los trabajadores que sirvan a un mismo empleador será de nacionalidad chilena. En cuanto a la edad mínima para contratar, el artículo 13 del Código del Trabajo la establece en 15 años.

60 LiZAMA, Luis y UGARTE, José Luis. Interpretación y derechos fundamentales en la empresa. Santiago, Chile: Editorial Jurídica ConoSur Ltda., 1998, pp. 230-235.
} 
Esto significa que, a la inversa de la mayoría de los textos constitucionales del derecho comparado y de los tratados internacionales que regulan la materia -como el Convenio No 111 sobre discriminación en el empleo y la ocupación, de la Organización Internacional del Trabajo $(1958)^{61}$, que establecen un conjunto de factores inadmisibles para establecer diferencias, exclusiones o preferencias-, nuestra Constitución ha optado por establecer que cualquier otro criterio que no se base en la aptitud o idoneidad personal constituye -en principio- un factor sospechoso de discriminación en materia laboral.

Es evidente que la técnica utilizada por nuestro constituyente resulta más adecuada que aquella propia del llamado "modelo antidiscriminatorio de sospecha cerrado", porque en este para que exista discriminación, se requiere que la diferencia de trato esté fundada en alguno de los criterios que se consideran indiciarios de un acto de discriminación ilegítima y que se encuentran taxativamente enumerados en la norma jurídica.

Esto significa que a las empresas les está prohibido discriminar a los trabajadores basándose en otros criterios que no sean la capacidad e idoneidad personal de estos. Desde esta perspectiva, entonces, la protección constitucional a la antidiscriminación es absoluta en nuestro país, en términos tales que cualquiera otra diferencia establecida entre los trabajadores o postulantes a un empleo que no sea estrictamente la señalada, constituirá discriminación laboral y el empleador habrá incurrido en un ilícito.

Sin embargo, a nivel legal, el Código del Trabajo establece una prohibición de discriminación en materia laboral que, a diferencia de la Constitución, mantiene el modelo tradicional impuesto por el Convenio No 111 de la Organización Internacional del Trabajo, a que hemos hecho referencia precedentemente, y enumera los criterios discriminatorios en su artículo $2^{\mathrm{o} 62}$.

De igual modo, es relevante la consagración, por vez primera, del principio de la libertad sindical, comprendiendo tanto su dimensión positiva (libertad de los trabajadores para constituir un sindicato y afiliarse a uno ya constituido) como negativa (libertad del trabajador para desafiliarse del sindicato o para no asociarse a ninguno).

Las modificaciones más relevantes introducidas a la legislación laboral a contar de 1978, fueron las siguientes:

a) El decreto ley No 2.200, de 1978, sobre contrato de trabajo y protección de los trabajadores.

b) El decreto ley No 2.756, de 1979, sobre organizaciones sindicales.

c) El decreto ley No 2.758, de 1979, sobre negociación colectiva.

d) El decreto ley No 2.759, de 1979, sobre asociaciones gremiales.

\footnotetext{
61 El Convenio No 111 sobre la discriminación (empleo y ocupación), de 1958, fue ratificado por la República de Chile el 20 de septiembre de 1971.

62 El artículo 2o del Código del Trabajo ha alterado el modelo adoptado por nuestra Constitución y ha provocado una severa dificultad de interpretación, porque algunos han entendido que si el criterio sospechoso de discriminación no se encuentra expresamente establecido por la ley sería posible establecer diferencias legítimas fundados en dicho factor, por ejemplo, respecto de los consumidores de drogas o de las personas que viven con el VIH. Al respecto, véase LizAMA, Luis. La discriminación laboral en Chile. Santiago, Chile (inédito), 2001.
} 
e) El decreto ley No 3.648, de 1981, que suprimió los tribunales del trabajo, otorgándole competencia laboral a los juzgados civiles ${ }^{63}$.

f) La ley No 18.018, de 1981, que modificó el decreto ley No 2.200, flexibilizando aún más la regulación del contrato individual del trabajo.

g) La ley No 18.032, de 1981, que establece normas sobre trabajadores portuarios.

Toda la nueva regulación laboral dictada en este período fue refundida en un nuevo Código del Trabajo, dictado en 1987.

Es indudable que la legislación laboral del gobierno militar incorpora contenidos ideológicos que se apartan de los tradicionales del derecho laboral chileno, proteccionista y tutelar de los derechos de los trabajadores, por razones que son explicadas con suma claridad por el ex ministro del Trabajo y Previsión Social del régimen, José Piñera:

"La normativa laboral chilena fue hija de 'corazones sangrantes' y de razonamientos débiles. Los textos de estudios parten invariablemente con inflamadas declaraciones de redención social, pero nada dicen acerca de cómo mejorar en realidad las condiciones de vida de la gente. No obstante que el mercado laboral es una realidad eminentemente económica -puesto que juega un rol clave en los conceptos de costo, productividad, competencia y demanda- el lenguaje que se usa es de fibra inconfundiblemente emocional. No hay político, no hay abogado con 'sensibilidad social', no hay agitador, no hay vicario 'progresista' ni hay comunicador social de 'avanzada', que no pueda dar en cualquier momento una encendida conferencia sobre el tema de la equidad en las relaciones laborales. Pero nunca esas proclamas contienen soluciones viables y coherentes a los problemas; son solo expresión de buenos deseos" ${ }^{64}$.

El decreto ley No 2.200 y el conjunto de cuerpos legales conocidos bajo el nombre de Plan Laboral (decretos leyes No 2.756, No 2.758 y No 2.759) constituyen el primer esfuerzo por flexibilizar el derecho laboral chileno ${ }^{65}$.

El concepto de flexibilidad del mercado de trabajo surgió en los países industrializados y en algunos países en desarrollo durante la década del ochenta, en el marco de las crisis económicas que se produjeron en Europa, y a partir de la idea de que la rigidez de las instituciones del derecho laboral les impedía absorber la oferta de mano de obra y adaptarse a las exigencias del cambio tecnológico y la competencia externa ${ }^{66}$.

\footnotetext{
63 La ley No 18.520, de 1988, restableció parcialmente los juzgados del trabajo y estableció un nuevo procedimiento para los juicios laborales

64 PIÑERA, José. La revolución laboral. Santiago, Chile: Editorial Zig-Zag, 1990, p. 53.

65 Sobre los antecedentes del Plan Laboral, véase Álamos, Rodrigo. "Nueva institucionalidad laboral”, en: Estudios Públicos No 26. Santiago, Chile: Centro de Estudios Públicos. Para una versión testimonial y anecdótica, véase PIÑERA, José, op. cit. (n. 64).

66 Sobre el concepto de flexibilidad del mercado de trabajo, véase, LAGOS, Ricardo A. "¿Qué se entiende por flexibilidad del mercado de trabajo?”, en: Revista de la Cepal No 54, pp. 81-95. Santiago, Chile: Comisión Económica para América Latina y el Caribe. Sobre la flexibilidad en Europa, véase BOYER, Robert. La flexibilidad del trabajo en Europa. Madrid, España: Centro de Publicaciones Ministerio del Trabajo y Seguridad Social, 1986. Dahrendorf, Ralf et al. Nuevas formas de trabajo y de actividad, Luxemburgo: Oficina de las Publicaciones Oficiales de las Comunidades Europeas, 1986. TreU, Triziano. "La flexibilidad laboral en Europa", en: Revista Internacional del Trabajo, vol. 112, No 2, pp. 217-223. Ginebra, Suiza.
} 
Por flexibilidad del mercado del trabajo se ha entendido "la capacidad de una empresa de ajustar el nivel y el calendario de los insumos de trabajo a los cambios de la demanda, de modificar el nivel de salarios según la productividad y la capacidad de pago, y de emplear a los trabajadores en tareas que atiendan las variaciones de la demanda" 67 .

Esta flexibilidad permitiría la adecuación eficiente de los recursos humanos disponibles en una empresa y se lograría mediante la reforma de las principales instituciones del derecho laboral, esto es, los contratos de empleo, el tiempo de trabajo, los sistemas de remuneración y la propia organización laboral ${ }^{68}$.

Desde una perspectiva teórica, se ha planteado que la flexibilidad del mercado de trabajo supone la consideración simultánea de factores que integran la flexibilidad numérica -externa e interna-, la flexibilidad salarial y la flexibilidad funcional ${ }^{69}$.

La flexibilidad numérica comprende dos aspectos: el ajuste continuado de la fuerza de trabajo y de las horas laborales. El primer aspecto recibe el nombre de flexibilidad numérica externa y consiste en la capacidad de la empresa de adecuar el número de los trabajadores, aumentándolos o disminuyéndolos, con el objeto de hacer frente a las fluctuaciones de la demanda de sus productos o servicios ofrecidos. El segundo aspecto se denomina flexibilidad numérica interna y trata de la libertad de las empresas para modificar el número de horas laborales sin variar el número de trabajadores.

La flexibilidad funcional es la capacidad de adecuar constantemente las labores desarrolladas por los trabajadores, a fin de adaptarse a los cambios tecnológicos y a la polivalencia exigida por los sistemas productivos modernos.

La flexibilidad salarial, también denominada flexibilidad financiera o de los costos laborales, es el grado de sensibilidad de los salarios nominales y los costos no salariales a las variaciones de las condiciones económicas en general y del desempeño de las empresas.

Ahora bien, desde el punto de vista de cómo incorporar la flexibilidad, se ha sostenido que esta podrá ser impuesta por el Estado mediante la reforma de la legislación o la interpretación de la autoridad administrativa ${ }^{70}$; podrá ser objeto de negociación colectiva

67 OZAKI, Muneto. Negociar la flexibilidad. Función de los interlocutores sociales y del Estado. Ginebra, Suiza: Oficina Internacional del Trabajo, 2000, p. 2.

68 Se ha sostenido que el concepto de flexibilidad del derecho del trabajo ha evolucionado desde aquel que planteaba que solo podía existir flexibilidad para proteger a los trabajadores (de protección), pasando por aquel que sostenía una adecuación de las normas legales rígidas a las nuevas circunstancias a través de la negociación colectiva (de adaptación), para devenir en la derogación lisa y llana de los beneficios laborales de los trabajadores (desregulación). Sobre el particular, véase JAVILLIER, JeanClaude. Droit du Travail. París, Francia: Librairie Générale de Droit et de Jurisprudence, 1999, pp. 145-160.

69 ALBIZú, Eneka. Flexibilidad laboral y gestión de los recursos humanos. Barcelona, Madrid: Editorial Ariel, 1997, pp. 17-21. Algunos autores han sostenido también la existencia de una flexibilidad "subterránea" que se ha desarrollado de hecho en Latinoamérica, pese a la existencia de instituciones del derecho laboral, estimulada por la dinámica interna del mercado de trabajo para responder a ciertos factores macroeconómicos, tales como la liberalización del comercio, la reducción de los subsidios estatales y la privatización de empresas pública. Sobre el particular, véase LAGOS, Ricardo A., op. cit. (n. 66), pp. 90-91. TOKMAN, Víctor y MARTínEZ, Daniel. "Efectos de las reformas laborales: Entre el empleo y la desprotección”, en: Flexibilización en el margen: La reforma del contrato de trabajo. Ginebra, Suiza: Oficina Internacional del Trabajo, 1999, pp. 11-27.

70 Al respecto, véase LizAMA, Luis. "Construcción dogmática de formas atípicas de contratación a través de los dictámenes de la Dirección del Trabajo”, en: IV Congreso Regional Americano de Derecho del Trabajo y de la Seguridad Social, Tomo I, pp. 183-193. Santiago, Chile, 1998. 
o de contratos individuales de trabajo; incluso, provenir de acuerdos unilaterales de los empleadores, o bien, de una combinación de todos ellos.

En el caso de la reforma laboral emprendida por el gobierno militar, se trató de una flexibilidad impuesta por el Estado, sin que mediara crisis económica, cuyo objeto principal fue reducir el contenido tutelar de la ley del trabajo ${ }^{71}$.

Esta flexibilización se refirió particularmente a las normas del derecho individual del trabajo, modificando las normas referidas a la contratación y término de la relación laboral, las condiciones de empleo y, en particular, materias salariales ${ }^{72}$.

En lo relativo a la contratación de trabajadores, la ley No 18.018 permitió pactar contratos de plazo fijo hasta por un máximo de 2 años, los que con la segunda renovación se transformaban en contratos de duración indefinida.

Respecto de las condiciones de trabajo, el decreto ley No 2.200 derogó todos los regímenes excepcionales de jornadas laborales de menos de 48 horas semanales, la prohibición de trabajo en días sábado y domingo, y las facultades administrativas de cierre obligatorio. Las normas sobre feriado progresivo se limitaron a la antigüedad con la empresa y no con el tiempo servido por el trabajador. En esta misma materia, se facultó al empleador para modificar la naturaleza de las labores y el lugar de trabajo sin el consentimiento del dependiente.

En cuanto a la flexibilidad salarial, se reemplazó el concepto de salario mínimo, que tenía una connotación de tarifa profesional, por el de ingreso mínimo mensual, y se modificó la institución de la participación en las utilidades. Finalmente, se excluye de la aplicación del ingreso mínimo mensual a los menores de 21 años y los mayores de 65 años.

La flexibilidad de salida fue la más radical de todas, porque el decreto ley No 2.200 faculta al empleador a despedir a los trabajadores sin expresión de causa a través de la institución del desahucio, hace incompatibles las indemnizaciones legales y convencionales, y elimina la obligación de reincorporar al trabajador cuando el despido había sido declarado injustificado por el juez. La ley No 18.018 fue más allá, al establecer un máximo de años a indemnizar legalmente limitado a 150 días de remuneración y limitar las disposiciones sobre despido colectivo.

Al contrario de la flexibilización del derecho individual, las normas que regularon la negociación colectiva y las organizaciones sindicales restringieron la autonomía colectiva e incrementaron la intervención legislativa en el modelo sindical. En opinión de algunos autores, esta rigidez del derecho sindical y el reglamentarismo excesivo en la negociación colectiva eran funcionales a la flexibilidad del derecho individual del trabajo ${ }^{73}$.

\footnotetext{
71 Según Carlos Hunneus, las modernizaciones emprendidas por el gobierno militar tuvieron un carácter parcial en lo relativo a la política laboral ya que esta "buscó privilegiar a los empresarios, recortando y cercenando los derechos de los trabajadores y debilitando el movimiento sindical”. Sobre el particular, véase HunNeUs, Carlos, op. cit. (n. 51), p. 394.

72 Al respecto, véase TAPIA GUERrero, Francisco, op. cit. (n. 32), pp. 71-94.

73 En el mismo sentido opina Óscar Ermida, quien ha sostenido que "la teología neoliberal procura derribar la legislación protectora de los derechos individuales del trabajador y mantener o aumentar la legislación restrictiva del derecho y actividades sindicales. La contradicción o desviación es obvia, máxime si se tiene en cuenta que salvo algún caso aislado, la legislación laboral latinoamericana se caracteriza por un moderado intervencionismo protector en las relaciones individuales y por un agudo intervencionismo represor de la actividad sindical, la autonomía colectiva y la autotutela, en el terreno de las relaciones colectivas de trabajo". Al respecto, véase ERMIDA, Óscar. "La flexibilidad en algunas experiencias comparadas", en: VV.AA.
} 
Evidencia de lo anterior es la circunstancia que el régimen sindical del Código del Trabajo de 1987 estableciera un conjunto de restricciones respecto de los sujetos colectivos, las materias negociables, los mecanismos de negociación y de conflicto ${ }^{74}$.

El sujeto colectivo estaba constituido en la empresa, con una pluralidad sindical, cuya afiliación era voluntaria.

La ley establecía un conjunto de prohibiciones respecto de materias que no eran negociables, limitando así la autonomía colectiva.

Los mecanismos de negociación, si bien se orientaban al acuerdo, ya sea mediante la obligación del empleador de contestar el proyecto de contrato colectivo con las condiciones vigentes debidamente actualizadas, o por medio de la facultad de prórroga del contrato colectivo por parte de los trabajadores involucrados en la negociación.

Finalmente, respecto de los mecanismos de conflicto, cabe destacar las restricciones para que los funcionarios públicos y determinados trabajadores que prestaban servicios en empresas de utilidad pública u otras similares pudieran ejercer el derecho de huelga.

\subsection{LAS REFORMAS LABORALES DE LOS GOBIERNOS DE LA CONCERTACIÓN}

Con la reinstalación del régimen democrático, en 1990, se plantearon un conjunto de reformas a la legislación laboral de la época, que se consideraban necesarias para dotarla de legitimidad. Para ello, el gobierno del presidente Aylwin definió una estrategia conocida como "crecimiento con equidad" que suponía conciliar en el plano laboral los intereses de los empleadores y trabajadores en un clima de crecimiento y estabilidad ${ }^{75}$.

El gobierno de la época definió cinco tareas de su política laboral, una de las cuales consistía en la dictación de una nueva legislación laboral ${ }^{76}$. Para ello, se codificaron las leyes otorgadas en el período 1990-1994 en un nuevo Código del Trabajo, cuyo texto refundido, coordinado y sistematizado fue fijado por el decreto con fuerza de ley No 1, del Ministerio del Trabajo y Previsión Social, de 1994, a saber:

a) La ley No 19.010, de 1990, que establece normas sobre terminación del contrato de trabajo y estabilidad en el empleo ${ }^{77}$.

Experiencias de flexibilidad normativa. Santiago Chile: Universidad Nacional Andrés Bello, 1992, pp. 31-54. Sobre el derecho colectivo latinoamericano, véase OJEDA, Antonio y ERMIDA, Óscar. La negociación colectiva en América Latina. Madrid, España: Editorial Trotta, 1993.

74 TAPIA GUerrero, Francisco, op. cit. (n. 32), pp. 94-102.

75 CORTÁzAR, René. "Una política laboral para una nueva realidad”, en: Políticas económicas y sociales en el Chile democrático. Santiago, Chile: Cieplan-Unicef, 1995, pp. 129-139.

76 Las otras tareas eran: acuerdos sociales que estimularen la cooperación, fortalecer la fiscalización del cumplimiento de la legislación laboral, perfeccionar el sistema de seguridad social y fomentar la capacitación y formación profesional.

77 Esta ley suprime el régimen general del despido o desahucio libre del Código de 1987. Se establece la obligación del empleador de invocar una causa justificada para terminar el contrato de trabajo, se incorporan las necesidades de la empresa, establecimiento o servicio como causal de despido de los trabajadores, se mantiene el desahucio para los gerentes, los trabajadores de casa particular y el personal de exclusiva confianza del empleador, se establece un régimen indemnizatorio a todo evento para los trabajadores de casa particular, se aumentan las indemnizaciones legales de 150 a 330 días de remuneración, se regula un sistema indemnizatorio a todo evento que contempla aportes en una A.F.P. y se reduce el término máximo del contrato a plazo fijo a 1 año. 
b) La ley No 19.049 , de 1991, sobre centrales sindicales ${ }^{78}$.

c) La ley No 19.069, de 1991, sobre organizaciones sindicales y negociación colectiva ${ }^{79}$.

d) La ley No 19.250, de 1993, que modifica los Libros I, II y V del Código del Trabajo, y otros textos legales ${ }^{80}$.

Esta nueva legislación laboral se orientaba sobre la base de tres principios: equidad, autonomía social y participación, y eficacia para el desarrollo.

De acuerdo con el ministro del Trabajo y Previsión Social de la época, René Cortázar, la equidad se manifestó, entre otras materias, en el aumento de cinco a once meses en el monto máximo de las indemnizaciones legales por término del contrato de trabajo, la eliminación de la discriminación respecto del feriado legal entre los trabajadores atendida la distribución de su jornada laboral, el perfeccionamiento de la institución del feriado progresivo, la fijación de ingresos mínimos para los trabajadores mayores de 65 años y los de casa particular, la determinación de condiciones mínimas de trabajo para los temporeros de la agricultura, la garantía de a lo menos un día de descanso en domingo para los trabajadores del comercio exceptuados del descanso dominical, una mejor regulación de la jornada laboral para los trabajadores de hoteles, restaurantes, buses, camiones, barcos pesqueros y casa particular, entre otras.

El segundo principio, de la autonomía social, se expresó en la regulación de la negociación colectiva y el reconocimiento del sujeto colectivo. Según René Cortázar, la legislación debía eliminar ciertas restricciones a la libertad sindical, como por ejemplo, reconocer el derecho de los trabajadores a constituir centrales sindicales y que sus dirigentes gozaran de fuero y permisos, suprimir la prohibición de constituir sindicatos de los trabajadores de temporada de la agricultura, permitir a los sindicatos de trabajadores eventuales suscribir convenios colectivos y, quizás, la reforma más importante, la eliminación de la prohibición de que los trabajadores negociaren más allá de la empresa en la que laboraban ${ }^{81}$. En el mismo sentido, con el objeto de favorecer a las organizaciones sindicales se fortaleció el fuero laboral y se aumentaron los permisos de los directores sindicales, se perfeccionaron los mecanismos de financiamiento de los sindicatos, e incluso, se creó una cotización a favor del sindicato que obtenía los beneficios que eran extendidos por el empleador a un trabajador no sindicalizado.

\footnotetext{
78 Esta ley, complementaria de la ley No 19.069 , tenía por objeto facilitar el reconocimiento de la Central Unitaria de Trabajadores, central sindical que apoyaba al Gobierno.

79 La ley No 19.069 regula las organizaciones sindicales y la negociación colectiva. Respecto de las organizaciones sindicales, las principales reformas estaban destinadas a facilitar la constitución de sindicatos en empresas pequeñas, interempresas y de trabajadores transitorios o eventuales, se amplía el fuero de los directores sindicales, se aumentan los permisos sindicales de 4 a 6 horas semanales y se introducen reformas simplificadoras sobre recaudación y descuento de cuotas sindicales. En cuanto a la negociación colectiva, se permite la negociación de convenios colectivos informales, se permite la negociación colectiva voluntaria a través de uno o más sindicatos interempresa, se amplían las materias que pueden ser objeto de negociación colectiva y se dispone la extensión de los beneficios de la negociación colectiva a otros trabajadores de la empresa con la obligación de cotizar un $75 \%$ de la cuota ordinaria al sindicato que negoció y obtuvo tales beneficios.

80 La ley No 19.250 es de carácter misceláneo y reforma el contrato individual del trabajo, algunos contratos especiales, las prácticas antisindicales y el procedimiento laboral.

81 La regulación de la negociación colectiva supraempresa con carácter voluntario se ha convertido en una norma programática que ha carecido de eficacia social, por la negativa de los empleadores de negociar de otro modo que no sea en la empresa.
} 
El principio de eficacia para el desarrollo supuso combinar regulación con políticas públicas, de modo tal que, al amparo de esta idea, se creó un fondo para la capacitación sindical y se dotó a la Dirección del Trabajo de los recursos financieros, materiales y humanos necesarios para el cumplimiento de sus funciones.

Sin perjuicio de lo anterior, resulta evidente que la política laboral del presidente Aylwin se encaminaba a propiciar relaciones bipartitas y equilibradas entre trabajadores y empresarios, reservando el rol del Estado exclusivamente a la regulación y fiscalización de las normas del trabajo. Las reformas laborales no tenían como propósito reemplazar el modelo de flexibilidad laboral adoptado durante el gobierno militar, sino que exclusivamente introducirle correcciones destinadas a rescatar el papel tutelar del derecho del trabajo.

Los gobiernos posteriores presentaron a la discusión parlamentaria propuestas legislativas destinadas a fomentar la negociación colectiva a través del desarrollo de la autonomía colectiva y el libre ejercicio del derecho de huelga, las que no han tenido éxito en el Congreso $\mathrm{Nacional}^{82}$. En esta materia, el principal logro ha sido la aprobación y ratificación, en 1999, de los Convenios No 87 y No 98 de la Organización Internacional del Trabajo, ambos referidos a la libertad sindical, cuya incorporación dio lugar a un interesante debate en la comunidad dogmática laboral acerca de sus efectos en la legislación interna ${ }^{83}$.

Las otras reformas legales han sido variopintas: se han referido a la no discriminación en el acceso al empleo ${ }^{84}$, a las responsabilidades compartidas de los trabajadores en el cuidado de los hijos menores ${ }^{85}$, al establecimiento de un régimen de seguro de cesantía ${ }^{86}$,

82 En 1994 se envío a tramitación parlamentaria un proyecto de ley que modificaba el Código del Trabajo en materia de negociación colectiva y otras (Mensaje No 423-330, de 1994), que contenía en su texto original el artículo 351-A, que hacía posible la flexibilización pactada por negociación colectiva de sistemas excepcionales de distribución de la jornada de trabajo y descansos; de suspensión de contratos individuales hasta por seis meses, y de reducción de la jornada de trabajo. Por primera vez se admitía la procedencia de la denominada "negociación colectiva peyorativa" o "a la baja", en la que los actores sociales pueden acordar rebajas de los derechos irrenunciables conferidos por la legislación laboral a los trabajadores. Este proyecto de ley, con indicaciones posteriores que eliminaban los reemplazantes durante la huelga y establecían un procedimiento de negociación colectiva con sindicatos interempresas, fue rechazado por el Congreso Nacional en diciembre de 1999.

83 Sobre el debate acerca de los efectos de la aprobación de los Convenios sobre libertad sindical, véase GAMONAL, Sergio. "El derecho chileno de negociación colectiva y los Convenios 87 y 98 de la OIT", en: Revista Laboral Chilena, vol. IX No 3, pp. 75-90. Santiago, Chile, 1999. Gamonal, Sergio. "Efectos de la ratificación de los Convenios 87 y 98 de la OIT, en el derecho colectivo chileno", en: Revista Laboral Chilena, vol. IX No 9, pp. 81-91. Santiago, Chile, 1999. LÓPEZ OnETO, Marcos. "El Convenio 87 de la OIT, Relativo a la Libertad Sindical y a la Protección del Derecho de Sindicación. Algunas Hipótesis sobre los Efectos de su Aplicación en el Orden Constitucional y Jurídico Laboral Chileno", partes I y II, en: Revista Laboral Chilena, vol. IX No 6, pp. 76 y ss. y vol. IX No 7, pp. 66 y ss. Santiago, Chile, 1999. UgarTe Cataldo, José Luis. "Libertad Sindical y Constitución: Cómo superar una vieja lectura”, en: Revista Laboral Chilena, vol. X No 4, pp. 69 y ss. Santiago, Chile, 2000. HALPERn, Cecily. "La certeza jurídica en la institucionalidad vigente en materia de relaciones colectivas del trabajo", en: Anuario de Derecho del Trabajo y de la Seguridad Social No 1, pp. 25-30. Santiago, Chile: Sociedad Chilena de Derecho del Trabajo y de la Seguridad Social, 2000. PaLAVECINO, Claudio. "La prohibición constitucional de huelga de los funcionarios públicos y los instrumentos internacionales", en: Anuario de Derecho del Trabajo y de la Seguridad Social No 1, pp. 31-44. Santiago, Chile: Sociedad Chilena de Derecho del Trabajo y de la Seguridad Social, 2000.

84 La ley No 19.591, de 1998, que prohibió los exámenes de embarazo a las postulantes a un empleo y la ley No 19.739, de 2001, que prohibió que en las ofertas de empleo se incluyeran criterios sospechosos de discriminación.

85 La ley No 19.505, de 1996, estableció el derecho de los padres trabajadores a un permiso para cuidar a los hijos menores de 18 años que sufran enfermedades o accidentes graves, y la ley No 19.760, de 2000, le concedió descanso postnatal y fuero a los trabajadores que en un procedimiento judicial de adopción les fuere conferido el cuidado personal de un menor.

86 La ley No 19.728, de 2001, estableció el régimen de seguro de cesantía, con prestaciones para los trabajadores que son financiadas con aportes efectuados por los empleadores, trabajadores y el Estado. 
al aumento de la edad mínima de los trabajadores ${ }^{87}$, a la responsabilidad subsidiaria de los contratistas $^{88}$, al establecimiento de un fondo para financiar el desarrollo sindical ${ }^{89}$, a una nueva regulación de la capacitación y formación profesional ${ }^{90}$, y al otorgamiento de nuevas facultades a la Dirección del Trabajo ${ }^{91}$.

Finalmente, es preciso señalar que a contar de 1992 se han ratificado 19 Convenios de la Organización Internacional del Trabajo, incluyendo aquellos que la propia organización ha establecido como necesarios para los efectos de proteger y respetar los derechos básicos de los trabajadores, en conformidad con la Declaración adoptada el 18 de junio de 1998, en Ginebra, durante la 86ª Reunión de la Conferencia Internacional del Trabajo, relativa a los principios y derechos fundamentales en el trabajo y su seguimiento.

Esta Declaración pretende conciliar "la preocupación por estimular los esfuerzos que todos los países dedican a lograr que el progreso social vaya a la par con el progreso de la economía, por una parte, con la de respetar la diversidad de situaciones, las posibilidades y las preferencias de cada país, por otra"92.

Para conseguir estos objetivos, se postula que los Estados que son partes de la Organización Internacional del Trabajo, con independencia de si han ratificado o no los convenios que consagran los derechos fundamentales de los trabajadores ${ }^{93}$, deben respetar, promover y hacer realidad, de buena fe y de acuerdo con la Constitución de la O.I.T., los principios relativos a tales derechos.

\section{EL DERECHO DEL TRABAJO CHILENO DE FINES DEL SIGLO XX}

Los autores chilenos están de acuerdo en que la legislación laboral vigente que regula el contrato individual, a fines del siglo XX, dispone de amplios factores de flexibilidad, tanto desde el punto de vista de la flexibilidad numérica, funcional y salarial ${ }^{94}$, y que, en cambio, la regulación del derecho colectivo no consagra adecuadamente la libertad sindical y la autonomía colectiva.

\footnotetext{
87 La ley No 19.673, de 2000, aumentó la edad mínima para trabajar de 14 a 15 años de edad.

88 La ley No 19.666, de 2000, permitió a los trabajadores demandar conjuntamente al empleador directo y a los responsables subsidiarios por las obligaciones laborales y previsionales incumplidas.

89 La ley No 19.644, de 1999, creó un Fondo para la modernización de las relaciones laborales y desarrollo sindical.

90 La ley No 19.518, de 1997, fijó el Nuevo Estatuto de Capacitación y Empleo.

91 La ley No 19.481, de 1996, le confirió facultades a la Dirección del Trabajo para fiscalizar las normas sobre higiene y seguridad en el trabajo.

92 Hansene, Michel. Presentación de la Declaración de la OIT relativa a los principios y derechos fundamentales en el trabajo y su seguimiento. Ginebra, Suiza: Oficina Internacional del Trabajo, 1998, p. 1.

93 De acuerdo al artículo 2 de la Declaración de la OIT, estos derechos fundamentales son: (a) la libertad de asociación y la libertad sindical y el reconocimiento efectivo del derecho de negociación colectiva, (b) la eliminación de todas las formas de trabajo forzoso, (c) la abolición efectiva del trabajo infantil, y (d) la eliminación de la discriminación en materia de empleo y ocupación.

$94 \mathrm{Al}$ respecto, véase TAPIA GUERRERO, Francisco, op. cit. (n. 32), pp. 57-105. VALDÉs, Alfredo. "Flexibilidad laboral”, en: Las relaciones de trabajo en el Chile de hoy. Santiago, Chile: Universidad de Chile, Programa de Relaciones Laborales, 1993, pp. 183-196. THAYER, William. "Orígenes, evolución y... (n. 1).
} 


\subsection{EL DERECHO INDIVIDUAL DEL TRABAJO 95}

La discusión que se ha generado en torno a la valoración de las consecuencias de la flexibilización del derecho individual, enfrenta a quienes sostienen que esta estrategia ha traído aparejada una mayor precarización de la fuerza de trabajo asalariada ${ }^{96}$ y a aquellos que postulan que no existe evidencia empírica que permita afirmar que la reforma laboral ha afectado las condiciones económicas de la población asalariada ${ }^{97}$.

Más allá de esta polémica, el derecho individual del trabajo se podría caracterizar de la siguiente manera:

\section{a) Absoluta flexibilidad para la contratación de trabajadores}

El derecho individual dispone de absoluta flexibilidad para que la empresa incorpore trabajadores, ya sea a través de la contratación atípica o de las modalidades de tercerización.

La contratación atípica supone la existencia de personal no estable en la compañía que se vincula a ella mediante contratos temporales (de plazo fijo y por obra o faena), el contrato de trabajo a tiempo parcial y los contratos de aprendizaje. Aunque la empresa también podría disponer de estudiantes en práctica profesional y de trabajadores a domicilio, sin que exista con ellos relación laboral alguna.

La tercerización le permite a la empresa contar con personal que trabaja para ella contratado a través de un tercero.

La subcontratación de bienes y servicios es una modalidad de tercerización a través de la cual una empresa (mandante) le encarga a otra (contratista) la ejecución de una o más tareas con sus propios trabajadores. Esta forma de descentralización productiva le ha permitido a la empresa nacional la externalización de partes o partidas completas de la elaboración de sus bienes y servicios, porque en nuestra legislación no se contempla la obligación de que sean producidos con trabajadores propios, ni siquiera respecto de sus actividades nucleares ${ }^{98}$.

La segunda modalidad de tercerización es el suministro de trabajadores, en que una empresa (suministradora) cede los trabajadores contratados por ella a otra (usuaria), tanto para el desempeño de labores temporales como permanentes en esta.

Esta figura que en términos estrictamente jurídicos es ilegal, porque de acuerdo con la ley laboral los dependientes tienen derecho irrenunciable a que se celebre su contrato con su

\footnotetext{
95 Esta parte reproduce -en lo pertinente- un trabajo de investigación realizado en el marco del Programa Derecho y Economía de la Universidad de Chile. Véase Lizama, Luis. “¿Qué y cuánta flexibilidad en el derecho individual del trabajo chileno?”, en: Taller No 2. Santiago, Chile: Programa Derecho y Economía, Facultad de Derecho, Facultad de Ciencias Económicas y Administrativas, Universidad de Chile, 2000.

96 EsCOBAR, Patricio. "Hacia una caracterización del mercado de trabajo", en: Trabajadores y empleo en el Chile de los noventa. Universidad Arcis, Programa de Economía del Trabajo. Santiago, Chile: LOM Ediciones, 1999, pp. 11-81.

97 EDWARDS, Sebastián y COX EDWARDS, Alejandra. "Reformas económicas y mercados laborales: Aspectos relativos a políticas y lecciones derivadas del caso chileno", en: Estudios Públicos No 78, pp. 45-100. Santiago, Chile: Centro de Estudios Públicos, 2000.

98 En el derecho comparado, la empresa contratista requiere desarrollar una actividad propia y específica, que sea diferente de la empresa principal, aunque complementaria y de colaboración con aquella. Al respecto, véase MARTíNEZ GARRIDO, Luis. Tratamiento laboral de la Contratación y Subcontratación entre empresas. Madrid, España: Fundación Confemetal, 1998, p. 20.
} 
empleador, ha adquirido gran importancia por el número de personas que laboran bajo esta modalidad y por la expansión que ha alcanzado en tan corto tiempo ${ }^{99}$.

Atendido lo anterior, no parece necesario introducir mayor flexibilidad numérica externa a nuestra legislación porque las modalidades de tercerización y de contratación atípica existentes le permiten a la empresa una suficiente capacidad para la entrada y salida de trabajadores, ajustando su plantilla a las fluctuaciones que se producen en el nivel del producto o servicio demandado.

Sin embargo, parece pertinente formalizar la modalidad del trabajo suministrado mediante la regulación de las empresas de trabajo temporal, a fin de evitar los abusos que se han generado en la contratación de trabajadores que ignoran quién es su empleador y que en la práctica quedan excluidos del ejercicio de determinados derechos laborales (vgr. el fuero laboral y los derechos colectivos $)^{100}$. Por lo demás, la existencia de un marco regulatorio para la actividad de las ETT debería redundar en beneficios para la libre competencia, al evitar la existencia de empresas que reducen sus costos laborales, contratando a los trabajadores que cederán a las compañías usuarias, sin sujeción al derecho laboral ${ }^{101}$.

\section{b) Libre despido de los trabajadores}

Las normas sobre el despido en Chile permiten una desvinculación rápida y fácil de los dependientes, en particular de los contratados temporalmente.

Asimismo, aunque se exija - por regla general- una causa justificada de término de la relación laboral, la causal de necesidades de la empresa, establecimiento o servicio ha operado en la práctica por la sola voluntad del empleador, como si se tratara de un verdadero desahucio porque los empleadores invocan esta causal aunque no exista alguna de las situaciones que justifica el despido ${ }^{102}$.

Ahora bien, en el caso que un trabajador despedido por la causal de necesidades de la empresa demandara por despido injustificado, improcedente o indebido ante los tribunales, podría obtener un eventual aumento del $20 \%$ de su indemnización por años de servicios una vez terminado el juicio, pero postergaría a esa fecha la percepción del monto ofrecido por su empleador. Si a ello se agrega que nuestra legislación laboral no contempla la nulidad del despido y el reintegro de los trabajadores en este caso ${ }^{103}$, podemos concluir que no exis-

\footnotetext{
99 En el derecho comparado, la cesión de trabajadores es procedente a través de las denominadas "empresas de trabajo temporal" que son aquellas cuya actividad consiste en poner a disposición de la empresa usuaria, con carácter temporal, trabajadores por ella contratados. Su objeto esencial lo constituye la intermediación triangular entre el trabajador que presta sus servicios y la empresa que los recibe.

100 UGARTE, José Luis. “Suministro de trabajadores y trabajo temporal: ¿Empresas sin trabajadores?”, en: Revista Laboral Chilena, vol. VIII No 6, pp. 76-90. Santiago, Chile, 1998.

101 Es una práctica extendida entre estas empresas contratar a sus trabajadores bajo la modalidad de honorarios. Al respecto, véase ECHEVERría, Magdalena et al. "El otro trabajo. El suministro de personas en las empresas", en: Cuadernos de Investigación No 7. Santiago, Chile: Departamento de Estudios, Dirección del Trabajo, 1998.

102 Tapia Guerrero, Francisco, op. cit. (n. 32), p. 92.

103 La legislación laboral chilena solo contempla el reintegro de los trabajadores que gozan de fuero laboral, en el evento que el empleador los haya despedido sin contar con la autorización judicial previa.
} 
te incentivo económico alguno para que un dependiente despedido por esta causal demande por despido injustificado ${ }^{104}$.

En consideración a lo anterior, parece necesario que los tribunales chilenos resuelvan los casos de término del contrato de trabajo no solo tomando en cuenta las causales legales de los artículos 159, 160 y 161 del Código del Trabajo, sino que también consideren si se ha o no infringido, por parte del empleador con ocasión del despido, un derecho fundamental, como por ejemplo, la no discriminación laboral ${ }^{105}$.

\section{c) Restricciones a la flexibilidad numérica interna: rigidez de la jornada laboral}

Pese a la rigidez de la regulación en materia de jornada de trabajo, el ajuste de esta se ha conseguido por la vía de la negociación individual y colectiva o, lisa y llanamente, a través del ejercicio del ius variandi por el empleador.

Asimismo, de manera muy significativa se ha conseguido la flexibilidad numérica interna a través de la facultad conferida al director del Trabajo por el inciso final del artículo 38 del Código del Trabajo, que le permite autorizar el establecimiento de un sistema excepcional de distribución de las jornadas y de los descansos en actividades exceptuadas del descanso dominical. En este caso, se calcula la jornada de trabajo sobre la base de una media mensual de 192 horas ${ }^{106}$.

Incluso, la Dirección del Trabajo ha autorizado estos pactos, tratándose de faenas que no están alejadas de centros urbanos. En estos casos, se ha exigido una solicitud conjunta del empleador y de las organizaciones sindicales, los sistemas excepcionales se han autorizado por un cierto plazo para su revisión, y se ha exigido el otorgamiento de descansos compensatorios adicionales por los días domingo o festivos que inciden en estas jornadas.

\footnotetext{
104 En el derecho comparado, en casos de despido abusivo, esto es, aquellos en los cuales el empleador no invoca una causal de despido o la causal invocada oculta las verdaderas motivaciones del despido, de naturaleza ilícita, como discriminaciones o persecución sindical, se configura el despido radicalmente nulo, la aplicación del principio de la no discriminación y la inversión de la carga de la prueba tratándose de prácticas antisindicales por el empleador en España, o la indemnización del daño material y moral producidos con ocasión de la ruptura abusiva del contrato de trabajo en Francia. Sin perjuicio de lo anterior, la construcción jurisprudencial más interesante se ha producido en Estados Unidos a través de la teoría del wrongful discharge, que ha limitado el derecho del empleador a poner libremente término a la relación laboral (employment at-will) sin ser responsable de daños, en aquellos casos en que se violen normas o principios públicos tales como aquellos que prohíben la discriminación laboral. Al respecto, véase, CANO GALÁN, Yolanda. El despido libre y sus límites en el derecho norteamericano. Madrid, España: Consejo Económico Social de España, Colección Estudios, 2000. Gould, William B. Agenda for reform. The future of the Employment Relationship and the Law. Cambridge, Estados Unidos: Massachusetts Institute of Technology, 1996.

105 Aunque nuestra jurisprudencia no ha admitido la teoría del despido discriminatorio, bajo cualquiera de las ideas señaladas, cabe consignar que tratándose de trabajadoras que gozan de fuero maternal contratadas a plazo fijo, la Corte Suprema ha sostenido la improcedencia de poner término al contrato de trabajo, "sin otra razón aparente que el vencimiento del plazo, lo que está en pugna con la garantía constitucional de la 'Indiscriminación Absoluta Laboral', contemplada en el artículo 19 No 16, inciso tercero de la Constitución Política de la República”. Al respecto, véase Corte Suprema, Rol No 6.165, de 6 de octubre de 1996, "Restaurante Quick Biss con Godoy Godoy, Susana” (queja), en: Revista Laboral Chilena, vol. VI No 12, p. 55. Santiago, Chile,1996. Lo más sorprendente del fallo es que la Corte Suprema resuelve contra texto expreso legal que la faculta para autorizar el desafuero de la trabajadora por vencimiento del plazo (artículo 174 inciso segundo del Código del Trabajo).

106 Este sistema le ha permitido al director del Trabajo establecer jornadas de 4 días de trabajo por 3 días de descanso, con 12 horas diarias (faenas mineras) o de 20 días de trabajo por 10 días de descanso, con 9,6 horas diarias (construcción).
} 
La flexibilidad de la jornada laboral es la que mayor falta le hace a nuestra legislación laboral, derivando su rigidez en un uso intensivo de las horas extraordinarias y la prolongación indebida de la jornada de trabajo. Por ello, cualquier reforma que permita un horario flexible, ya sea a través de la anualización de la jornada de trabajo o la flexibilización en la organización del tiempo de trabajo diario o semanal, redundará en un objetivo social deseable, cual es la reducción de la jornada laboral.

\section{d) Flexibilidad funcional y polivalencia de los trabajadores}

En nuestra legislación laboral, la empresa puede utilizar el ius variandi para obtener movilidad funcional y geográfica ${ }^{107}$, o pactar cláusulas de "polifuncionalidad" en los contratos individuales de trabajo, a condición que se precisen en forma clara e inequívoca las tareas o funciones a las que se obliga el dependiente ${ }^{108}$.

\section{e) Flexibilidad salarial y ausencia de participación en las utilidades de la empresa}

En nuestro país, la flexibilidad salarial se ha asociado con la posibilidad de pactar remuneraciones variables ligadas a la productividad, individual o colectiva de los trabajadores, y a las presiones competitivas de los costos ejercidas por el mercado ${ }^{109}$.

Sin perjuicio de lo anterior, también cabe tener en cuenta que los únicos márgenes existentes en la legislación laboral en esta materia son, básicamente, el ingreso mínimo mensual y la gratificación legal.

Respecto del ingreso mínimo mensual se ha discutido su alto incremento en relación con el crecimiento de los salarios promedios de la economía, en la última década, y la incidencia de este aumento en el desempleo de los jóvenes ${ }^{110}$.

Sin embargo, respecto de la participación en las utilidades de la empresa mediante la gratificación legal no existe mayor cuestionamiento a su existencia, probablemente porque nuestra legislación ha establecido una modalidad flexible que le permite al empleador pagar a sus trabajadores el $25 \%$ de lo devengado en el respectivo ejercicio comercial por concepto de remuneraciones mensuales con un tope de 4,75 ingresos mínimos mensuales, en vez de repartir el 30\% de las utilidades líquidas producidas entre sus trabajadores.

En lo que se refiere a la flexibilidad salarial, quizás sea necesario reformular la institución de la gratificación legal, atendido el hecho que ha perdido su sentido original, esto es,

107 El ius variandi, previsto en el artículo 12 del Código del Trabajo, es la potestad del empleador de variar o alterar, dentro de ciertos límites, las condiciones de la prestación de los servicios. Esta facultad del empleador que puede ejercer en forma unilateral no es arbitraria, ya que debe encuadrarse dentro de ciertos límites previstos por la ley. El empleador puede alterar, unilateralmente, la naturaleza de los servicios o el sitio o recinto en que los servicios deban presentarse.

108 LiZAMA, Luis. "La interpretación administrativa de la legislación laboral”, en: Revista Laboral Chilena, vol. VIII No 8, pp. 65-75. Santiago, Chile, 1998.

109 En efecto, de acuerdo a la Encuesta Laboral de 1999 de la Dirección del Trabajo, el 49\% de las empresas de la muestra declararon que aplicaban incentivos de productividad en las remuneraciones pagadas a sus trabajadores. Un estudio anterior del Departamento de Estudios de la Dirección respecto de inclusión de cláusulas de productividad en instrumentos colectivos arrojó cifras más conservadoras, a saber: 42,8\% en empresas grandes (200 y más trabajadores), 33,7\% en las empresas mediadas (entre 50 y 199 trabajadores) y 23,3\% en las empresas pequeñas (hasta 49 trabajadores. Al respecto, véase, VERGARA, Mónica. "Productividad, salarios y negociación colectiva", en: DireCción Del Trabajo. Temas Laborales No 10, p. 9. Santiago, Chile, 1998.

110 BeYer, Harald. “Notas sobre el desempleo”, en: Puntos de Referencia No 231, pp. 6 y ss. Santiago, Chile, 1999. 
ser un instrumento que permitía repartir a los trabajadores los beneficios conseguidos en la empresa. En la actualidad, la gratificación no pasa de ser un bono asimilado al sueldo de los trabajadores, que no tiene nada que ver con utilidades ni beneficios.

Por ello, es posible debatir en otras formas de participación en los beneficios de la empresa que sean alternativos al actual sistema en vigencia. Por ejemplo, los planes de stock options pueden resultar una estrategia interesante para compensar a los trabajadores ${ }^{111}$, tomando en cuenta la flexibilidad financiera con la que operan: ni las empresas ni los trabajadores requieren contar con dinero, ya sea al momento de ofrecer la opción de compra, o al tiempo de ejercerlas ${ }^{112}$.

\section{f) El derecho colectivo del trabajo chileno}

En la actualidad, el derecho positivo colectivo del trabajo chileno vigente presenta diversos caracteres que pueden sintetizarse de la siguiente forma ${ }^{113}$ :

\section{- Incoherencia normativa}

A nivel de fuentes, la Constitución y diversos tratados internacionales sobre derechos humanos, vigentes en Chile, consagran la libertad sindical en nuestro sistema jurídico.

Sin embargo, a nivel legal, el Código del Trabajo estructura un sistema a espaldas de las normas constitucionales e internacionales vigentes, transgrediendo con mucho la libertad sindical consagrada en los mismos.

Cabe agregar que una parte importante de la doctrina maneja un concepto absolutamente formalista y restrictivo de libertad sindical, como derecho de formar sindicatos y adherir libremente a los mismos (libertad sindical en faceta individual), sin contemplar la negociación colectiva y la huelga (libertad sindical en faceta colectiva).

- Excesiva regulación de los sindicatos

El Código del Trabajo destina su Libro III a la regulación de las organizaciones sindicales, a través de una normativa de detalle que muchas veces transgrede la libertad sindical.

En este nivel encontramos preceptos de fomento de la actividad sindical, como los relativos a la adquisición de personalidad jurídica, los permisos sindicales o la disolución de sindicatos solo por sentencia judicial ${ }^{114}$.

Por otra parte, encontramos una serie de disposiciones limitativas de la libertad sindical, a saber, las normas de determinación de la tipología sindical, sobre los requisitos para ser candidatos a directores, número de dirigentes, adopción de cuotas, destino de los bienes del sindicato una vez disueltos, fiscalización del manejo patrimonial por parte de la Direc-

\footnotetext{
111 La ley de Oferta Pública de Acciones permite a las sociedades anónimas ofrecer programas de compensación de sus trabajadores que les permitan adquirir acciones de la compañía a un precio preferente. No obstante la ausencia de una regulación tributaria especial para las stock options en el proyecto referido hace imposible implementar estos planes de compensación por los elevados costos impositivos que asumirían los beneficiarios y las empresas.

112 Sobre el particular, véase, SCOTT, Rodrick et al. The Stock Options Book. Estados Unidos: The National Center for Employee Ownership, 1999.

113 En este apartado, colaboró el profesor de derecho del trabajo Sergio Gamonal.

114 Se discute si la disolución acordada por voluntad de los afiliados requiere también de sentencia judicial.
} 
ción del Trabajo, prácticas antisindicales, constitución y afiliación a federaciones y confederaciones, etc.

- Sobrerreglamentación de la negociación colectiva

El Código conforma un marco regulatorio reglamentarista, que contempla con detalle cada etapa desde el inicio hasta el término del proceso negociador.

El procedimiento negociador contemplado es bastante rígido y busca orientar el conflicto por una vía de solución pacífica, evitando el recurso a la huelga en desmedro de los trabajadores.

Se consagra la obligatoriedad de negociar y de contratar, vulnerando la libertad sindical. No obstante, dicha obligatoriedad se hace necesaria ante la prohibición general de huelga, salvo en los casos en que haya fracasado la negociación y se cumplan una serie de requisitos legales.

- $\quad$ Limitación de los mecanismos de autotutela

La Constitución solo consagra una prohibición amplia de huelga en el sector público y en los servicios esenciales.

A nivel legal, la huelga legítima se circunscribe a la etapa final del proceso negociador, siempre que se cumplan todos los requisitos legales. Se permite además que el empleador contrate reemplazantes o esquiroles dentro de ciertos requisitos legales.

Además, el concepto de huelga en que se basa la legislación es restrictivo, en cuanto abstención colectiva de trabajo, sin considerar las evoluciones recientes de las últimas dos décadas que amplían dicho concepto a toda perturbación del proceso productivo.

- $\quad$ Olvido de los intereses colectivos

Sin perjuicio de la discusión doctrinaria acerca de este tipo de intereses, se dan situaciones objetivas en toda empresa donde el sindicato representa en forma indirecta y expansiva a todos los trabajadores, por ejemplo, en materia de seguridad y medio ambiente de trabajo.

El Código pareciera ignorar esta realidad y regular a los sindicatos como entes que cumplen una suerte de representación civil.

- Omisión del sector público

Se prohíbe que el sector público negocie y contrate colectivamente, así como que estos funcionarios puedan ir a la huelga.

En este punto se produce la mayor brecha entre legislación y realidad, ya que son frecuentes las movilizaciones en dicho sector y los "acuerdos o protocolos de entendimiento" que, en el fondo, son instrumentos colectivos. 


\section{LA DOCTRINA DEL DERECHO DEL TRABAJO CHILENO A FINES DEL SIGLO XX}

Para concluir esta apretada síntesis del derecho chileno del trabajo durante el siglo XX, esbozaré críticamente los rasgos que me parecen más característicos de la comunidad dogmática laboral.

\section{A) LA CONFUSA NOCIÓN DE LOS PRINCIPIOS DEL DERECHO DEL TRABAJO}

El surgimiento del derecho del trabajo, como hemos visto, está imbuido de un contenido ideológico particular, que lo transformó en un derecho especial con principios jurídicos que le son propios.

De la idea que el derecho laboral constituye en sí una disciplina cuyo contenido tutelar de los derechos de los trabajadores determina cierta autonomía institucional, dogmática y científica, se ha inferido la existencia de un conjunto de principios, que constituyen el fundamento de la ordenación del trabajo asalariado, y que son válidos en cualquier ordenamiento laboral.

Esta noción de la validez universal de los principios del derecho del trabajo ha sido sostenida por el jurista uruguayo Américo Plá en su obra Los principios del derecho del trabajo ${ }^{115}$, que ha influido notoriamente en la jurisprudencia y doctrina nacionales.

Para Plá, los principios constituyen líneas directrices que informan algunas normas e inspiran directa e indirectamente una serie de soluciones, por lo que pueden servir para promover y encauzar la aprobación de nuevas normas, orientar la implementación de las existentes y resolver los casos no previstos, de modo tal, que existe una interrelación entre las normas del derecho vigente y los principios, que opera por mutua influencia entre am$\operatorname{bos}^{116}$.

Esta idea de la existencia de ciertos principios generales que son cosustanciales al derecho laboral, cuya función es actuar como medio integrador de vacíos normativos y como criterio orientador del intérprete, ha provocado una gran confusión al momento de construir dogmáticamente los principios jurídicos del sistema laboral chileno.

Así, se han obviado los principios constitucionales del derecho laboral chileno, tales como la libertad sindical y la no discriminación absoluta; y a la inversa, se han incorporado principios extrasistémicos que son propios del derecho comparado y, que, en algunos casos, no es posible inferir como normas implícitas o como principios inexpresos pero implícitos en nuestro sistema jurídico laboral ${ }^{117}$.

115 PLÁ, Américo. Los principios del Derecho del Trabajo. Buenos Aires: Editorial Depalma, -3a edición-, 1998. La primera edición data de 1975.

116 Para Plá, los principios del derecho del trabajo son los siguientes: El principio protector, el principio de la irrenunciabilidad de los derechos, el principio de continuidad de la relación laboral, el principio de la primacía de la realidad, el principio de la razonabilidad y el principio de la buena fe.

117 En nuestra comunidad dogmática, el profesor Juan Carlos Soto Calderón ha planteado que los principios generales del derecho del trabajo son los siguientes; tutelar; del orden público laboral; de la normatividad mínima; de la concreción; de la sobrerregulación jurídica; de la integración normativa; y de la universalización. Sobre los principios del derecho del trabajo chileno, véase GAMONAL, Sergio, "Introducción al derecho... (n 58), pp. 127-178. LizAma, Luis, "La Dirección del Trabajo... (n. 47), pp. 80-87. 
Por lo anterior, nos parece necesario avanzar en una construcción que dé cuenta del desarrollo de la noción de principios en la teoría del derecho, a partir de las contribuciones de Dworkin, Aarnio, Alexy y Wróblewski, y que soslaye los elementos ideológicos que han provocado la confusión aludida.

\section{B) LA AUSENCIA DE TENDENCIAS DOCTRINARIAS EN EL DERECHO DEL TRABAJO CHILENO}

La discusión teórica actual acerca del derecho del trabajo se ha centrado entre las corrientes flexibilizadoras del derecho laboral y quienes sostienen la vigencia de su carácter protector, exigiendo un rol más activo del Estado en la defensa de los derechos de los trabajadores.

Este debate se ha planteado en términos muy simples y carentes de una discusión ideológica de fondo. Está lleno de descalificaciones mutuas, carece de un lenguaje común -los términos flexibilidad, desregulación y rerregulación son ambiguos y vagos- y ha girado en derredor de la reforma emprendida por el gobierno militar.

Sin embargo, no existe un desarrollo doctrinal que utilice el instrumental de que proporciona el análisis económico del derecho o también llamado law \& economics ${ }^{118}$ ni tampoco corrientes críticas vinculadas al uso alternativo del derecho o critical legal studies $^{119}$.

No obstante lo anterior, en el último tiempo se ha comenzado a generar un debate interesante acerca de los nuevos temas del derecho laboral ${ }^{120}$, aunque existen tópicos respecto de los cuales la ausencia de investigación es evidente ${ }^{121}$.

\section{C) LA ECONOMÍA DESPLAZA AL DERECHO DEL TRABAJO EN LA DECISIÓN LEGISLATIVA SOBRE LA RELACIÓN LABORAL \\ Existe suficiente evidencia sobre la pérdida de influencia de nuestra comunidad dog-} mática en la discusión legislativa sobre las reformas emprendidas a la legislación laboral.

De este modo, no constituye una casualidad que el Plan Laboral emprendido por el gobierno militar a contar de 1978, así como las reformas laborales posteriores impulsadas

\footnotetext{
118 Aisladamente, se han publicado dos trabajos: LizAma, Luis. "El análisis económico del trabajo y la ley de Accidentes del Trabajo y Enfermedades Profesionales", en: Estudios en homenaje al profesor William Thayer. Santiago, Chile: Sociedad Chilena de Derecho del Trabajo y de la Seguridad Social, 1998, pp. 146-165. UGARTE, José Luis. "El derecho del trabajo y sus enemigos. Aproximación al análisis económico del derecho”. Salamanca, España: Universidad de Salamanca, 2001.

119 A diferencia de lo que ocurre en Chile, tanto en Argentina como en España existen publicaciones que acogen las teorías críticas contra la flexibilidad laboral. Así en Argentina se publica, desde 1997, Contextos. Revista Crítica de Derecho Social, y en España, desde 1998, la Revista de Derecho Social. En España, véase BAYLOS GraU, Antonio. Derecho del Trabajo: modelo para armar. Madrid, España: Editorial Trotta, 1991. En Chile existe una agrupación de ex becarios de la Universidad de Bologna, que podrían aparecer vinculados a las teorías críticas dentro del derecho laboral, con una fuerte influencia de la Escuela Italiana dirigida por los juristas Umberto Romagnolli y Tiziano Treu. Esta agrupación realiza seminarios anualmente pero no mantiene una publicación permanente.

120 En el paradigmático texto de Alain Supiot es posible encontrar un conjunto de novedosos temas que nuestra comunidad dogmática no ha abordado adecuadamente, como la ciudadanía en la empresa, la parasubordinación, entre otros. Al respecto, véase, SuPIOT, Alain. Crítica del Derecho del Trabajo. España, Madrid: Informes y Estudios, Ministerio del Trabajo y Asuntos Sociales, 1996.

121 Sin perjuicio de lo anterior, es importante señalar que existen publicaciones permanentes orientadas a la divulgación doctrinaria, como la Revista Laboral Chilena y el Anuario de Derecho del Trabajo y de la Seguridad Social.
} 
por los gobiernos de la Concertación, hayan sido inspiradas por economistas con formación en el extranjero como los ministros del Trabajo y Previsión Social, José Piñera (1979-1981) y René Cortázar (1990-1994) ${ }^{122}$, quienes desplazaron la opinión de los juristas con formación tradicional en el derecho del trabajo.

De igual manera, es evidente que el debate sobre los temas laborales ya no es prerrogativa exclusiva de los juristas, sino que también participan de él, activamente, los mencionados economistas y también sociólogos ${ }^{123}$.

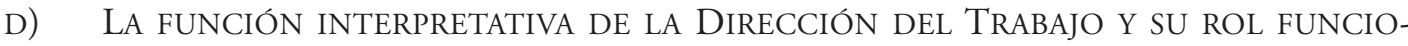
NAL EN LA DOGMÁTICA LABORAL CHILENA

La Dirección del Trabajo es un órgano de la Administración del Estado que tiene competencia para fiscalizar e interpretar la legislación laboral chilena. La interpretación administrativa de la ley que realiza la Dirección del Trabajo tiene por objeto facilitar la fiscalización de la legislación laboral y dar coherencia y uniformidad a la supervigilancia de la aplicación correcta de las normas que interpreta.

La producción normativa de la Dirección del Trabajo ha provocado una merma relevante del desarrollo de la doctrina laboral en nuestra comunidad, porque el trabajo interpretativo es realizado por un conjunto de especialistas que conciben su función como una tarea sujeta a un modelo general de comportamiento y de conocimiento ${ }^{124}$.

Por ello, la discusión dogmática más relevante sobre temas controvertidos no obtiene una decisión judicial, sino que administrativa a través de los dictámenes ${ }^{125}$. De hecho, la resolución judicial se ha centrado en la calificación de las causales de terminación del contrato de trabajo y en la revisión de las actuaciones fiscalizadoras de la propia Dirección del Trabajo, existiendo un conjunto de tópicos respecto de los cuales los jueces no se han pronunciado.

\footnotetext{
122 José Piñera es economista de la Universidad Católica y Doctor en Economía en la Universidad de Harvard y René Cortázar es economista de la Universidad Católica y Doctor en Economía en el Massachusetts Institute of Technology. Para una versión personal de los procesos modernizadores de la legislación laboral que ambos impulsaron, véase PIÑERA, José, op. cit. (n. 64). CORTÁZAR, René. Una política laboral para una nueva realidad.

123 En la discusión sobre las reformas laborales durante la década del noventa participaron activamente economistas, sociólogos y juristas.

124 Es tal la importancia de la decisión interpretativa de la Dirección del Trabajo, que sus dictámenes son recopilados en el Boletín Oficial de la Dirección del Trabajo, y, además, se publican otras revistas que también contienen su jurisprudencia administrativa, dirigidas a empleadores, trabajadores, organizaciones sindicales y académicas, a saber: Boletín del Trabajo de la Asociación de Profesionales de la Dirección del Trabajo; Manual de Consultas Laborales y Previsionales y Revista Técnica del Trabajo de la Asociación de Funcionarios del Trabajo de Chile. Estas publicaciones también se encuentran disponibles en Internet (Revista Técnica del Trabajo) y en soporte magnético (Boletín del Trabajo). La Editorial Jurídica de Chile en Internet y el Diario Oficial de la República en soporte digital administran bases de datos con la jurisprudencia administrativa de la Dirección del Trabajo. Incluso, el Código del Trabajo de Juan Díaz Salas que fue publicado en 26 volúmenes, contenía los dictámenes de la Dirección del Trabajo desde su primer tomo. Al respecto, véase DíAZ SALAS, Juan. Código del Trabajo. Santiago: Editorial Zig-Zag, 1941.

125 En la comunidad dogmática laboral existen diversas opiniones acerca del carácter jurídico de los dictámenes emitidos por la Dirección del Trabajo. Esta querella ha confrontando posiciones divergentes entre quienes postulan -con distintos argumentos- que el dictamen constituiría una fuente formal propia del derecho del trabajo, y aquellos que han sostenido que la decisión interpretativa de la Dirección del Trabajo es solo una mera opinión sin ningún valor jurídico. Aunque, no obstante esta discusión, más propia de la teoría del derecho que del derecho laboral, los autores chilenos -incluso aquellos sin opinión respecto del debate- hacen referencia a lo señalado por la Dirección del Trabajo en sus dictámenes, al exponer nuestras instituciones laborales en sus obras.
} 
Este rol funcional ha sido explicado por las similitudes que existen entre el modo de producción jurídica de la Dirección del Trabajo y los jueces de la tradición angloamericana, atendido el hecho que los dictámenes construyen soluciones a partir del caso que luego se extienden a través de la noción del precedente.

\section{BIBLIOGRAFÍA}

Álamos, Rodrigo. "Nueva institucionalidad laboral”, en: Estudios Públicos No 26. Santiago, Chile: Centro de Estudios Públicos.

AlBIZÚ, Eneka. Flexibilidad laboral y gestión de los recursos humanos. Barcelona, Madrid: Editorial Ariel, 1997.

Allende, Salvador. Obras escogidas (1970-1973). Barcelona, España: Editorial Crítica, 1989.

Baylos Grau, Antonio. Derecho del Trabajo: modelo para armar. Madrid, España: Editorial Trotta, 1991.

BeYER, Harald. "Notas sobre el desempleo”, en: Puntos de Referencia No 231, pp. 6 y ss. Santiago, Chile, 1999.

BOyER, Robert. La flexibilidad del trabajo en Europa. Madrid, España: Centro de Publicaciones Ministerio del Trabajo y Seguridad Social, 1986.

CANO Galán, Yolanda. El despido libre y sus limites en el derecho norteamericano. Madrid, España: Consejo Económico Social de España, Colección Estudios, 2000.

Congreso Nacional. Cámara de Diputados. Boletín de Sesiones Ordinarias de la Cámara de Diputados.

CORTÁZAR, René. "Una política laboral para una nueva realidad”. En: Políticas económicas y sociales en el Chile democrático. Santiago, Chile: Cieplan-Unicef, 1995, pp. 129-139.

DAHRENDORF, Ralf et al. Nuevas formas de trabajo y de actividad, Luxemburgo: Oficina de las Publicaciones Oficiales de las Comunidades Europeas, 1986.

DESHAZO, Peter. Urban workers and labor unions in Chile, 1902-1927. University of Wisconsin Press, 1983.

DíAZ SALAS, Juan. Código del Trabajo. Santiago: Editorial Zig-Zag, 1941.

ECHEVerría, Magdalena et al. "El otro trabajo. El suministro de personas en las empresas", en: Cuadernos de Investigación No 7. Santiago, Chile: Departamento de Estudios, Dirección del Trabajo, 1998.

EDWARDS, Sebastián y COX EDWARDS, Alejandra. "Reformas económicas y mercados laborales: Aspectos relativos a políticas y lecciones derivadas del caso chileno”, en: Estudios Públicos No 78, pp. 45-100. Santiago, Chile: Centro de Estudios Públicos, 2000.

ERMida, Óscar y Villavicencio, Alfredo. "El Comité de Libertad Sindical”, en: Revista Derecho Laboral, Tomo XXXVI, No 169, pp. 82-83. Montevideo, Uruguay.

ERMIDA, Óscar. "La flexibilidad en algunas experiencias comparadas", en: VV.AA. Experiencias de flexibilidad normativa. Santiago Chile: Universidad Nacional Andrés Bello, 1992, pp. 31-54.

ESCOBAR, Patricio. "Hacia una caracterización del mercado de trabajo”. En: Trabajadores y empleo en el Chile de los noventa. Universidad Arcis, Programa de Economía del Trabajo. Santiago, Chile: LOM Ediciones, 1999, pp. 11-81.

Escríbar Mandiola, Héctor. Tratado de Derecho del Trabajo. Santiago, Chile: Editorial Zig-Zag, 1944.

GAMOnal, Sergio. "Efectos de la ratificación de los Convenios 87 y 98 de la OIT, en el derecho colectivo chileno", en: Revista Laboral Chilena, vol. IX No 9, pp. 81-91. Santiago, Chile, 1999.

GAMONAL, Sergio. “El derecho chileno de negociación colectiva y los Convenios 87 y 98 de la OIT”, en: Revista Laboral Chilena, vol. IX No 3, pp. 75-90. Santiago, Chile, 1999.

GAMOnal, Sergio. Derecho colectivo del trabajo (inédito).

GAmOnaL, Sergio. Introducción al Derecho del Trabajo. Santiago, Chile: Editorial Jurídica ConoSur Ltda., 1998. 
Gould, William B. Agenda for reform. The future of the Employment Relationship and the Law. Cambridge, Estados Unidos: Massachusetts Institute of Technology, 1996.

Grez Toso, Sergio. De la "regeneración del pueblo" a la huelga general. Génesis y evolución histórica del movimiento popular en Chile (1810-1890). Santiago, Chile: Colección Dibam, Ediciones Ril, 1997.

GUZMÁN BRITO, Alejandro. "Codificación, descodificación y recodificación del derecho civil chileno", en: Revista de Derecho y Jurisprudencia y de Gaceta de los Tribunales, Tomo 90, No 2, pp. 39-62. Santiago, Chile: Editorial Jurídica de Chile.

HALPERN, Cecily. "La certeza jurídica en la institucionalidad vigente en materia de relaciones colectivas del trabajo", en: Anuario de Derecho del Trabajo y de la Seguridad Social No 1, pp. 25-30. Santiago, Chile: Sociedad Chilena de Derecho del Trabajo y de la Seguridad Social, 2000.

HANSENE, Michel. Presentación de la Declaración de la OIT relativa a los principios y derechos fundamentales en el trabajo y su seguimiento. Ginebra, Suiza: Oficina Internacional del Trabajo, 1998.

Hunneus, Carlos. El régimen de Pinochet. Santiago, Chile: Editorial Sudamericana, 2001.

IRTI, Natalino. La edad de la descodificación. Madrid, España: Editorial José Bosch, 1992.

JaVILlier, Jean-Claude. Droit du Travail. París, Francia: Librairie Générale de Droit et de Jurisprudence, 1999.

LAGOS, Ricardo A. “¿Qué se entiende por flexibilidad del mercado de trabajo?”, en: Revista de la Cepal No 54, pp. 81-95. Santiago, Chile: Comisión Económica para América Latina y el Caribe.

LIZAMA, Luis y UGARTE, José Luis. Interpretación y derechos fundamentales en la empresa. Santiago, Chile: Editorial Jurídica ConoSur Ltda., 1998.

LiZAMA, Luis. “¿Qué y cuánta flexibilidad en el derecho individual del trabajo chileno?”, en: Taller No 2. Santiago, Chile: Programa Derecho y Economía, Facultad de Derecho, Facultad de Ciencias Económicas y Administrativas Universidad de Chile, 2000.

LIZAMA, Luis. "Construcción dogmática de formas atípicas de contratación a través de los dictámenes de la Dirección del Trabajo”, en: IV Congreso Regional Americano de Derecho del Trabajo y de la Seguridad Social, Tomo I, pp. 183-193. Santiago, Chile, 1998.

LIZAMA, Luis. "El análisis económico del trabajo y la ley de Accidentes del Trabajo y Enfermedades Profesionales", en: Estudios en homenaje al profesor William Thayer. Santiago, Chile: Sociedad Chilena de Derecho del Trabajo y de la Seguridad Social, 1998, pp. 146-165.

LIZAMA, Luis. "La interpretación administrativa de la legislación laboral”, en: Revista Laboral Chilena, vol. VIII No 8, pp. 65-75. Santiago, Chile, 1998.

LIZAMA, Luis. La Dirección del Trabajo: una explicación de su facultad de interpretar la legislación laboral chilena. Santiago, Chile: Fundación Facultad de Derecho, Universidad de Chile, 1998.

LizAMA, Luis. La discriminación laboral en Chile. Santiago, Chile (inédito), 2001.

LÓpez Oneto, Marcos. "El Convenio 87 de la OIT, Relativo a la Libertad Sindical y a la Protección del Derecho de Sindicación. Algunas Hipótesis sobre los Efectos de su Aplicación en el Orden Constitucional y Jurídico Laboral Chileno", partes I y II, en: Revista Laboral Chilena, vol. IX No 6, pp. 76 y ss. y vol. IX No 7, pp. 66 y ss. Santiago, Chile, 1999.

MARTínez GARRIDO, Luis. Tratamiento laboral de la Contratación y Subcontratación entre empresas. Madrid, España: Fundación Confemetal, 1998.

MORRIS, James O. Las elites, los intelectuales y el consenso. Estudio de la Cuestión Social y del sistema de relaciones industriales de Chile. Santiago, Chile: Editorial del Pacífico, 1967.

Oficina Internacional del Trabajo. La Situación Sindical en Chile. Informe de la Comisión de Investigación $y$ de Conciliación en Materia de Libertad Sindical. Ginebra, Suiza, 1975.

OJEDA, Antonio y ERMIDA, Óscar. La negociación colectiva en América Latina. Madrid, España: Editorial Trotta, 1993. 
OZAKI, Muneto. Negociar la flexibilidad. Función de los interlocutores sociales y del Estado. Ginebra, Suiza: Oficina Internacional del Trabajo, 2000.

PALAVECINO, Claudio. "La prohibición constitucional de huelga de los funcionarios públicos y los instrumentos internacionales", en: Anuario de Derecho del Trabajo y de la Seguridad Social No 1, pp. 31-44. Santiago, Chile: Sociedad Chilena de Derecho del Trabajo y de la Seguridad Social, 2000.

Palomeque, Manuel-Carlos y Álvarez de la Rosa, Manuel. Derecho del Trabajo -6a edición-. Madrid, España: Editorial Centro de Estudios Ramón Areces, S.A., 1998.

PAlomeque, Manuel-Carlos. Derecho del Trabajo e Ideología. Madrid, España: Editorial Tecnos, 2011.

Palomeque, Manuel-Carlos. Derecho del Trabajo e Ideología. Medio siglo de formación ideológica del Derecho español del trabajo (1873-1923). Madrid, España: Editorial Tecnos, 1980.

PIÑERA, José. La revolución laboral. Santiago, Chile: Editorial Zig-Zag, 1990.

PLÁ, Américo. Los principios del Derecho del Trabajo. Buenos Aires: Editorial Depalma -3a edición-, 1998.

Poblete Troncoso, Moisés. El Derecho del Trabajo y la Seguridad Social en Chile. Santiago, Chile: Editorial Jurídica de Chile, 1949.

Ramírez Necochea, Hernán. Origen y formación del Partido Comunista de Chile. Santiago, Chile: Editorial Austral, 1965.

SCOTT, Rodrick et al. The Stock Options Book. Estados Unidos: The National Center for Employee Ownership, 1999.

SupIOT, Alain. Crítica del Derecho del Trabajo. España, Madrid: Informes y Estudios, Ministerio del Trabajo y Asuntos Sociales, 1996.

TAPIA GUERrero, Francisco, "La flexibilidad en el derecho del trabajo chileno". En: VV.AA. Experiencias de flexibilidad normativa. Las transformaciones del derecho del trabajo. Santiago, Chile: Universidad Nacional Andrés Bello.

THAYER, William. "Notas sobre génesis y desarrollo del derecho del trabajo en la República de Chile". En: VV.AA. Derecho del Trabajo: Normas y realidad. Estudios en homenaje al profesor Ramón Luco Larenas. Santiago, Chile: Universidad Nacional Andrés Bello, 1992, pp. 75-100.

THAYER, William. "Orígenes, evolución y perspectivas del derecho laboral chileno", en: Estudios Públicos No 54, pp. 223-240. Santiago, Chile: Centro de Estudios Públicos.

TOKMAN, Víctor y MARTíneZ, Daniel. "Efectos de las reformas laborales: Entre el empleo y la desprotección”. En: Flexibilización en el margen: La reforma del contrato de trabajo. Ginebra, Suiza: Oficina Internacional del Trabajo, 1999.

Treu, Triziano. "La flexibilidad laboral en Europa", en: Revista Internacional del Trabajo, vol. 112, No 2, pp. 217-223. Ginebra, Suiza.

Ugarte Cataldo, José Luis. “Libertad Sindical y Constitución: Cómo superar una vieja lectura”, en: Revista Laboral Chilena, vol. X No 4, pp. 69 y ss. Santiago, Chile, 2000.

UGARTE, José Luis. "El derecho del trabajo y sus enemigos. Aproximación al análisis económico del derecho". Salamanca, España: Universidad de Salamanca, 2001.

UGARTE, José Luis. “Suministro de trabajadores y trabajo temporal: ¿Empresas sin trabajadores?”, en: Revista Laboral Chilena, vol. VIII No 6, pp. 76-90. Santiago, Chile, 1998.

VALDÉs, Alfredo. "Flexibilidad laboral”, en: Las relaciones de trabajo en el Chile de hoy. Santiago, Chile: Universidad de Chile, Programa de Relaciones Laborales, 1993, pp. 183-196.

Vergara, Mónica. "Productividad, salarios y negociación colectiva", en: Dirección Del Trabajo. Temas Laborales No 10, p. 9. Santiago, Chile, 1998.

Walker Errázuriz, Francisco. Derecho del Trabajo y Relaciones del Trabajo. Santiago, Chile: Editorial Jurídica Ediar ConoSur Ltda., 1984.

Walker Linares, Francisco. Nociones Elementales del Derecho del Trabajo -4a edición-. Santiago, Chile: Editorial Nascimento, 1947. 